\title{
Bilge Karasu’nun Metinlerinde Birey ve Kaçış Arzusu*
}

\section{The Individual and the Desire of Escape in Bilge Karasu's Texts}

\author{
Ataberk Hacimale ${ }^{1}$ (1)
}

*Bu çalışma, 2020 yılında İstanbul Üniversitesi Sosyal Bilimler Enstitüsü Türk Dili ve Edebiyatı Anabilim Dalı Yeni Türk Edebiyatı Bilim Dalında, Doç. Dr. Mehmet Samsakçı danışmanlığında savunulan "Bilge Karasu'nun Metinlerinde Firar Psikolojisi ve Bireyin Durumu" başlıklı yüksek lisans tezinden üretilmiştir.

'Boğaziçi Üniversitesi, Sosyal Bilimler Enstitüsü, Türk Dili ve Edebiyatı Bölümü, İstanbul, Türkiye

ORCID: A.H. 0000-0003-1617-0410

Sorumlu yazar/Corresponding author: Ataberk Hacımale,

Boğaziçi Üniversitesi, Sosyal Bilimler Enstitüsü, Türk Dili ve Edebiyatı Bölümü, İstanbul, Türkiye E-mail: atahacimale@gmail.com

Başvuru/Submitted: 17.11.2020

Revizyon Talebi/Revision Requested: 29.11.2020 Son Revizyon/Last Revision Received: 01.12.2020 Kabul/Accepted: 01.12.2020

\section{Atıf/Citation:}

Hacimale, A. (2021). Bilge Karasu'nun metinlerinde birey ve kaçış arzusu. TUDED, 61(1), 151-176.

https://doi.org/10.26650/TUDED2020-827208

\section{ÖZET}

Edebi eserin biçimi ve dili üzerine yaptıkları yeni arayışlar, 1940 sonrasında yetişmiş olan Türk Edebiyatı kuşağının en çok göze çarpan özelliklerinden biridir. Bu kuşağın önde gelen isimlerinden olan Bilge Karasu, edebi metnin biçimi ve diline dair yaptığı arayışlarla bu çabanın ciddi takipçilerinden birisi konumundadır. Yine de Bilge Karasu'nun metinleriyle onun edebiyata katkısı nispetinde ilgilenilmediği ve edebiyat araştırmacılarının bu konuya hak ettiği ağırlığı vermediği açıktır. Bu makale, Karasu'nun metinlerini farklı bir açıdan ele almayı ve eksik kalmış bu alana bir katkı sunmayı amaçlamaktadır. Bilge Karasu'nun metinleri, yazarın içinde bulunduğu firar psikolojisinden yola çıkarak yakın okumaya tabi tutulmuş, Karasu'nun hayatının "gölgesinin" ve edebiyata olan yaklaşımının eserlerini ne şekilde etkilediği açıklanmıştır. Makale, temel olarak üç bölümden meydana gelmektedir: Birinci bölüm, kişinin yaşantısını doğrudan etkileyen bir konu olan firar psikolojisinin, meselenin çeşitli boyutlarıyla birlikte ele alınarak açıklanmasına ayrılmışıı. Yenilikçi yazarların metinlerinde kendisini gösteren kaçış anlatısının modern Türk Edebiyatında ne şekilde bir eğilim meydana getirdiği, makalenin ikinci bölümünde ortaya konmuştur. Üçüncü bölüm, çalışmanın temel konusu olan Bilge Karasu'yu yaşamı ve kurgu dışı yazılarından yola çıkıp firari bir yazar olarak ele almaya ve yazarın metinlerinin bu perspektif üzerinden açıklanmasına ayrılmıştır.

Anahtar Kelimeler: Bilge Karasu, kaçış, birey, gelenek, firar psikolojisi

\section{ABSTRACT}

Explorations in form and language are prominent features of the post-1940s Turkish Literature generation. Bilge Karasu, one of the most remarkable names of this generation, is known for his experimental practices with the image and utterance of a literary work. This article aims to take a holistic approach to Karasu's texts and address his literature from a different perspective. The texts of Bilge Karasu were analyzed based on the psychology of escape that the author experienced, and we reviewed how the shadow of Karasu's life and his approach to literature affect his works. The article is divided into three parts: the explanation of the psychology of escape, which is a subject that directly affects the life of the person; the place of escape psychology in Turkish literary tradition; and the explanation of Bilge Karasu as a fugitive writer based on his life and nonfiction writings and an explanation of the writer's texts from this perspective.

Keywords: Bilge Karasu, escape, individual, tradition, psychology of escape 


\section{EXTENDED ABSTRACT}

Bilge Karasu has been a part of the literary canon for many years as a leading figure in Turkish literature. However, in literary studies, Karasu's texts are not given as much importance as they deserve. One clear reason is that the language of his texts is difficult to understand, and his ambiguous style may deter literary researchers. However, as anyone who has read Karasu's texts will attest, the individual and his fragmented world are always at the center of the author's works.

The psychology of the modern individual has a very fragmented structure. The state of the individual is directly related to the knowledge that he has. The world view, education, value judgments, and experiences of the individual directly affect his life practices. It is obvious that the individual will feel like a stranger to his cultural values if he does not comply with the community in which he lives. The alienated individual is inevitably driven to escape. It is natural for people who have failed to build a healthy self, due to their childhood experiences, to encounter bonding problems in their adult lives. Individuals whose psyche has been hurt turn to various defense mechanisms to avoid injury in their relations with the society. Turning toward defense is a sign of the individual's escape from society and indicates that the person is in the psychology of escape. Escape can arise from the inner self, or it can develop as a result of pressure from the society to the person.

The exploration of escape is prevalent in literature. The entire literary history, from Lucretius to Lübeck, from Novalis to Hesse, has been a field where fugitive characters show themselves. From the beginning of modern Turkish literature, fugitive individuals have stood out. The fugitive writers' distance from traditional narrative techniques paves the way for the theme of escape to be addressed more widely in literary works. The fugitive writers, who put the fugitive individual at the center of the text, do not stay away from people's problems as it is thought. On the contrary, the writer touches on the issues of society when describing the problems of the fugitive. That is exactly makes the theme of escape in modern Turkish literature meaningful.

The first representative of fugitive writers in the modern period is Beşir Fuad, a person whose entire life was defined by escaping from his society and world. He spent his whole life with pursuing a new identity. This search ended with suicide. The theme of escape has perhaps most clearly manifested itself in the works of the Servet-i Fünun group. All members of the Servet-i Fünun ensemble deeply felt the desire to escape and reflected this in their literature. Tevfik Fikret, exhausted from the oppressive environment of Istanbul, retreated to voluntary exile in Aşiyan. The most competent example of the fugitive characters in literary texts until the new era is Ahmet Cemil in Halit Ziya's novel Mai ve Siyah. The escape of Ahmet Cemil, the protagonist of the novel, aligns with the escape of a whole generation of Servet-i Fünun. Fugitive writers and poets continued to produce works during the republican period, and the fugitive characters followed each other on a line in literary works. 
Bilge Karasu has given some of the most competent examples of fugitive characters in modern Turkish literature. Karasu, who reveals a fugitive personality with his life and identity, has put the modern individual's escape at the center of his literary works. Karasu, who comes from a Jewish family and identifies as homosexual, lived a life limited to a narrow circle of friends to avoid scandal. He has been a person whom in the psychology of escape throughout his life for the reasons we have stated. When viewed from this point of view, the writer's texts are both a continuation of the fugitive characters line in modern Turkish literature and a reflection of the author's life itself. He wrote many texts in different literary genres, and although each of these texts is shaped around different topics, the theme each has in common is the issue of escape. The individual is at the center of these texts and is written from the perspective of the desire to escape. The main subject of Karasu's texts is the individual's psychology of escape. 


\section{GİRIŞ}

Bilge Karasu, Modern Türk edebiyatının önde gelen isimlerinden biri olarak Türkiye'deki edebiyat ortamının önemli bir parçasıdır. Ancak Karasu metinleriyle, bu metinlerin hak ettiği ölçüde ilgilenilmediği açıktır. Bunun yazara ve araştırmacıya bağlı olarak değişen birçok sebebi vardır; Bununla birlikte yazarın metinlerinin dilinin zorluğu ve kullandığı kapalı üslubun da edebiyat araştırmacılarının yazarın edebiyatıyla ilgilenmekten uzak durmasında bir rolü olduğu barizdir. Karasu'nun birey ve onun parçalı dünyasını ele alması, metinlerinin değerlendirilmesini zorlaştırmaktadır. Şurası açıktır ki Karasu'nun metinlerinin merkezinde her zaman için birey ve onun parçalı dünyası vardır.

Modern bireyin psikolojisi, çok parçalı bir yapıya sahiptir. Geçmişte içedönük bir cemaatin içinde yaşamaya alışkın olan insan, modernliğin kendisini kaçınılmaz şekilde dayatmasıyla birlikte birey haline gelmiş ve bu da bireyin parçalı bir kimliğe bürünmesine sebep olmuştur. Bireyin içinde bulunduğu durum, sahip olduğu bilgiyle doğrudan ilişkilidir. Bireyin dünya görüşü, eğitimi, değer yargıları ve tecrübeleri onun hayatı yaşama pratiklerini doğrudan etkilemektedir. Sahip olduğu kültürel değerler, içinde bulunduğu toplulukla uyum göstermediği durumda bireyin kendisini oraya yabancı hissedeceği barizdir. Yabancılaşan birey, bunun sonucunda kaçışa sürüklenir. Çocukluğunda yaşadığı tecrübelerden dolayı sağlıklı bir kendilik inşa etmeyi başaramamış kişilerin yetişkinliklerinde bağlılık sorunları yaşaması doğaldır. Psikolojisi sakatlanmış bireyler, toplumla ilişkilerinde yara almamak için çeşitli savunma mekanizmalarına yönelirler. Savunmaya yönelmek, bireyin toplumdan kaçışının belirtisidir ve kişinin firar psikolojisi içerisinde olduğunu gösterir. Firar, bireyin içsel benliğinden doğabileceği gibi toplumdan kişiye yönelen baskı sonucunda da açığa çıkabilir. Kitlenin ve iktidarın baskısını üzerinde hisseden birey, bundan kurtulabilmek için kaçışa sürüklenir. Ancak bireyin bir defa kaçmaya başlaması, bir yere bağlanmanın son derece zorlaşmasıyla sonuçlanır. Kaçış hali, kendi kendisini besleyen bir süreçtir. Toplumsal yaşamın başlangıcından itibaren kendisini göstermiş bir durum olan kaçış fikri, moderniteyle birlikte modern bireyin önemli sorunlarından birisi konumuna gelmiştir.

Edebiyat, modern bireyin önemli sorunlarından biri olan kaçışı "konusu" haline getirmiştir. Dünya edebiyatı, kaçışı merkezine almış metinlerle doludur. Başlangıcından itibaren modern Türk edebiyatı da kaçışı önemli bir tema olarak ele almış, firari karakterlerin merkezde olduğu çok sayıda metin üretimine sahne olmuştur. Kendi yaşantısında firar psikolojisi içerisinde olan, bununla beraber edebi metinlerinde de firar psikolojisi içerisinde bulunan karakterleri merkeze alan yazar ve şairler, bu üretimin taşıyıcı isimleri haline gelmiştir. Firari yazar ve şairlerin kaleme aldığı edebi eserler sonucu ortaya firari karakterlerden meydana gelen oylumlu bir külliyat çıkmış, Türk edebiyatında kaçış anlatısı başı başına bir eğilim haline gelmiştir. Bilge Karasu, edebi üretimiyle bu kaçış anlatısı eğiliminin bir sürdürücüsüdür. Onun metinleri, bireyin içinde bulunduğu firar psikolojisi üzerinden şekillenmiş, eksik modern bireyin kaçış içindeki dünyası bütün edebi yapıtlarına yansımıştır. Kendi yaşamında da firar psikolojisi içerisinde bir yazar olan Karasu'nun metnine kendi hayatı yansımıştır. 
Modern Türk edebiyatındaki kaçış anlatısıyla firari yazar Karasu'nun yaşantısı metinlerin ortaya çıkışını şekillendirmiştir.

Firari yazar Karasu'nun metinlerini kaçış merkezli bir okumaya tabi tutmak için, önce bireyi kaçışa sürükleyen sebeplerin etraflıca açıklanması gerekir. Bunun ardından, Beşir Fuad'la başlayıp Bilge Karasu'ya ulaşan Türk edebiyatındaki firari yazarlar çizgisine göz atmak, Karasu'nun Türk edebiyatının neresine konumlandığını daha iyi anlayabilmek için önem teşkil eder.

\section{Firar Psikolojisi}

Modern insan, bir iç çatışmanın içerisine düştüğünde çareyi genellikle bulunduğu durumdan kaçmakta bulur. Bu kaçış fikri, fiziksel olarak yer değiştirme anlamına gelebileceği gibi bireyin kendisini psikolojik olarak diğer her şeyden soyutlaması şeklinde de açığa çıkar. Modernite, bireyin iç dünyasında daha önce karşı karşıya olmadığı yeni problemlere yol açmıştır. Alışık olmadığı yeni sorunlarla yüzleşirken birey çoğu zaman bir başınadır ve çözümü bulma konusunda zorluk yaşar. Bu sebeple modern birey çoğu defa karşı karşıya olduğu sorunları yadsıma eğiliminde olurken kendisini firar psikolojisinin içerisinde bulur. Sorunlar karşısında kaçış arzusu ilk çağlardan itibaren kendisini insana dayatmıştır, ancak geçmişin fiziksel olarak firari insanı yerini toplum içerisinde sıkışmış modern bireylere bıraktıkça firar psikolojisi zamanla bir olgu olarak daha çok önem kazanmaya başlar. Lucretius'tan Lübeck'e, Novalis’ten Hesse'ye dek edebiyat tarihi kişinin içinde bulunduğu firar psikolojisini metnin merkezine koymuş firari yazarlarla ve bu yazarların kaleme aldığı edebi metinlerle doludur.

İlk olarak dikkat edilmesi gereken husus, bireyi ait olduğu yerden firar etme eğilimine sürükleyen şeyin temelde, kişinin sahip olduğu bilginin durumu olduğudur. Bilginin doğruluk değeri görelidir; bilginin doğru olarak kabul edilmesi kişinin kimliğiyle ve içinde bulunduğu ortamla karşılıklı bir ilişki içindedir. Bireyin içinde bulunduğu toplumla uyum sağlayamadığ 1 durumlarda yaşadığı ortamla çatışma içerisine girmesi olağan bir hadisedir. Aynı şekilde toplumun yıllar içerisinde oluşmuş kültürel kodlarının ve yaşayış şeklinin de bazı kişilere yabancı gelmesi pek de şaşırtıcı olmayacaktır. Bu tarz sorunlar, bireyle kolektif yapı arasında tarih boyunca açığa çıkmış ve benzer psikolojik tepkilere sebep olmuştur. Birey ile içinde yaşadığ 1 yapı arasında var olan anlaşmazlık durumunda bir çatışma ortaya çıkar. Bu çatışmanın temelinde, birey ile toplum arasında yaşanan uyum sorunu bulunur. Bireyin psikolojik dünyası id ile üstben arasındaki çatışmadan dolayı halihazırda yıpranmış durumdayken, buna bir de dış dünyayla yaşadığı sorunlar eşlik eder. Böyle bir durumda olan kişinin önünde iki seçenek bulunur: Birey ya bu çatışmanın ortasında kaybolup nevroza sürüklenir, ya da topluma ve diğer bireylere karşı kurduğu savunma mekanizmasıyla bu durumun üstesinden gelir. Görmezden gelme, bir kaçış mekanizması olarak etkili bir savunma aracıdır, içinde bulunduğu sorunla yüzleşmekten çekinen birey kurtuluşu kaçışta bulur. Ancak firar, gerçek anlamda bir sorun çözme yolu değildir. Birey, çatışmadan kaçarak sorunlarını yalnızca halının altına süpürmüş olur. Bununla birlikte, her çeşit sorunu göz ardı ederek kaçış içerisine girmek, bireyin bilinçaltında 
etkisi süreğen bir sızı bırakır. Firar hali, kişiyi kendi kuyruğunu yiyen ouroboros yılanı gibi devamlı benzer pattern'ler içerisinde davranmaya zorlar. Firar psikolojisinin bireyin iç dünyasında yol açtığı en büyük hasarlardan biri budur.

Masterson'ın tanımına göre "kendilik tasarımı", kişinin belirgin bir dönem ve anda kendi kişiliğine dair sahip olduğu imajdır (Masterson, 2016, s. 41). Bireyin kendilik tasarımı temelde iki şeye dayanır: Fiziksel yapı ve psikolojik durum. Kişinin sahip olduğu kendilik tasarımı, gerçekçi bir imaj olabileceği gibi bilinçdışının çarpık bir yansıması da olabilir. Bireyin farklı dönemlerde oluşturduğu çeşitli tasarımları ego aracılığıyla bir araya gelir ve "kendilik temsilini" oluşturur. Bu temsil, kişinin bilinçli ya da bilinçsiz anlarındaki temsilini sağlar. Bireyi firara sürükleyen de tam olarak bu temsilin sahte kendilik kimliği olmasıyla ortaya çıkar. Masterson, kişinin kendilik temsilinin toplumla uyum kurmada sorun yaşamaması için benin oluşum sürecinin sağlıklı bir şekilde sağlanmış olması gerektiğini ileri sürer. Sahte kendilik kimliğine sığınan bireyse gerçeklerden kaçıp savunma mekanizmalarına yönelir. Bu durum, uç örneklerde çeşitli psikolojik rahatsızlıklara yol açsa da sıradan insanların da çeşitli dönemlerde gerçeklikten kaçtığg zamanlar vardır. Çatışmadan kaçış, modern bireyin kaçınılmaz yazgısıdır.

Bireyin uyaranlara karşı verdiği tepkiler belirli şablonlara uygun şekilde gerçekleştiği için, kişinin bir olgu karşısında nasıl tavır aldığını bilmek, benzer durumlarda ne tür bir kaçış içerisine gireceğini anlamak açısından yardımcı olur. Ben, içinde bulunduğu çatışmayı aşabilmek için bütün silahlarını tek seferde kullanma eğilimindedir. Bu sebeple çeşitli savunma yöntemleri aynı anda benzer amaçlar için kullanılabilir. Anna Freud, benin sahip olduğu savunma mekanizmalarını bastırma, gerileme, tepki oluşturma, yapıp bozma, yansıtma, içe yansıtma, yalıtma, kendine yöneltme, karşıtına çevirme, yüceltme ya da dürtü hedefinin yer değiştirmesi şeklinde sıralar (Freud, 2017, s. 37). Bireyin kırgın psikolojik dünyasına dış dünyadan yönelmiş tehditlerden kaçmak için kullandığı savunma araçları genel hatlarıyla bunlardır.

Bireyi kaçış arzusuna sürükleyen şey temelde nedir? İd'in pompaladığı isteklerle başa çıkmaya çalışan, kendisinde bulunan olumsuz bütün özellikleri karşıtına yükleyerek bundan kurtulmak isteyen ve en önemlisi, içinde yaşadığ 1 hakikati reddeden birey, firar psikolojisinin etkisi altındadır. Kişi zaman zaman dış dünyanın kendi üzerindeki baskı ve tedirgin edici eylemlerinden, zaman zamansa nesneyle arasında sağlıklı bir ilişki kuramamasının sebep olduğu uyum sorunları yüzünden firar psikolojisine sürüklenir. Açıç̧a gözüken şeyse şudur ki, birey kendisine yönelen baskı ve sınırlamalara uyum sağlayabildiği sürece kendisini bir yere ait hisseder. Kişi, yüzleşmiş olduğu sınırlamalarla çatışma içerisine girdiği her anda kendisi için acı verici bir tecrübe olan bu durumdan kaçarak firari birey haline gelir.

Sigmund Freud, insanın yaşamdaki temel amacının mutluluğa erişmek olduğunu söyleyerek bunu "haz ilkesi programı" olarak açıklar. Kişiyi en kısa yoldan mutluluğa eriştirecek olan şeyse id'in arzu ettiği her şeyi yerine getirerek arzuyu doyurmaya çabalamasıdır. Ancak mutluluk hiçbir zaman sonsuza dek sürmez, üstelik dürtüye her defasında boyun eğen insanın bir üst yapı tarafından cezalandırılma riski her zaman için mevcuttur. Birey, karşılaşma ihtimali 
bulunan cezadan sıyrılmak için haz ilkesini bir kenara bırakarak toplumsal yapının emir ve yasaklarını yerine getirmeye karar verir. Bu şekilde haz ilkesi yerini gerçeklik ilkesine bırakır. Benin arzularını tatmin etmeyi bir kenara bırakması boşuna değildir, bunu yapmaktaki temel motivasyonu, hazzı takip edecek olan ikincil cezalandırmadan kaçmaktır (Freud, 2017, s. 48). Cezadan kaçan birey, arzularını tatmin etmek için yeniden firara sığınır ve gerçeğin acı verici dünyasını bir süreliğine bırakıp fantezi dünyasına kaçmanın yollarını aramaya başlar. Ancak fanteziye kaçış aşırıya vardırıldığında yeni sorunlara yol açar. Gerçeklikten fanteziye firar, eğer uç noktalara taşınmışsa bireyin uyum sorunlarının iyice artmasına ve gerçek dünyayla bağının giderek zayıflamasına neden olur.

Ben, kendisini kırılgan hissettiğinde arzularına erişebilmek için bir başka kişiyi aracı kılma yoluna gidebilir. Bireyin kendi benliğini bir kenara bırakarak var gücüyle bir başkasının mutluluğu için çabalaması firar psikolojisinin görünümlerinden biridir. Kendisi için istemekten çekindiği bir statü ya da hedefe bir başkasının ulaşması için elinden geleni yapan birey, bu kişinin arzu ettiği hedefe ulaşmasından kendisi başarılı olmuşçasına sevinecektir. Birey, kendi benliğinin arzu ve isteklerini geri planda tutarak hedefine dolayımlı şekilde ulaşır.

Heinz Hartmann'ın da belirttiği gibi, bazı spesifik anlarda ben, çevreyle daha fazla iletişim kuramayacak bir ruh haline bürünür. Bu anlar benin, varoluş amacını yitirdiğini hissettiği zamanlardır ve o güne dek kurmuş olduğu ilişkileri bile sağlıklı şekilde sürdüremeyecek bir hale gelir. Benin böyle bir durumla karşı karşıya kalması, dışa dönük benliğini askıya alarak iç dünyasına sığınacağı ve yeni bir başlangıç yapmak için çabalayacağını gösterir. Bireyin içine düştüğü bu tarz bir çatışmanın kaynağı kişinin şahsi çevresinden gelen baskıların yol açtığı karmaşadır. Bu durumda benin göstereceği otomatik tepki, durumu yadsımak olur. Hartmann, yadsımanın kaçışa dayandığını belirtir, özel olarak bir şeyden kaçınmanın temeliyse açıkça kaçıştır (Hartmann, 2016, s. 31). Yadsıma da, kaçınma da sonunda benin kısıtlanmasıyla sonuçlanır. Firar halinde bulunan bireyin kişiliğini sağlıklı bir şekilde inşa edebilmesi çok zordur. Bireyin kaçışı, kendisini daha mutlu hissedeceği bir yere varmasıyla olumlu şekilde sonuçlanabilir, bunun kişiliğini oluşturmasına sunacağı pozitif katkı tartışılmazdır. Ancak firar, her zaman için umut edilen yere ulaşmayla sonuçlanmaz. Başlangıç anından kaçan, ancak hiçbir yere varamayan birey ortada kalır ve psikolojik olarak “yersiz yurtsuz” olmanın acısını çeker.

Haset, çocuklukta edinilen bir olgu olarak bireyin ileriki yaşlarında suçluluk duygusu taşımasına sebep olur. Suçluluk duygusuysa, bireyi firara sürükleyen sebeplerin başında gelir. Klein, bireyin çocuklukta nesneyle kurduğu sağlısız ilişkinin gelecekte uyumsuz bir birey haline gelmesinde etkili olduğu görüşünü savunur (Klein, 2020, s. 23). Çocuğun hasedinin yöneldiği ilk nesne, onun sonsuz arzularını tatmin etme imkanına sahipken bebekliğinde kendisinden esirgenen -ya da esirgendiğini düşündüğü- anne memesidir. Bebeğin dünyaya gelişiyle birlikte, sahip olduğu bütünlüklü yaşam sona erer. Artık isteklerini istediği anda elde ettiği konforlu gelişim evresi geride kalmıştır. Anne memesini emmek bebeğe ihtiyacı olan sütü ve güvenlik duygusunu sağlar, ancak anne sütü sınırsız bir kaynak değildir, bu nedenle memeyle bebeğin doğru aralıklarla bir araya gelmesi çok önemlidir. Bebek, anne memesinin 
kendisinden bilinçli olarak esirgendiğini düşündüğü zaman haset duygusu gelişir. Haset duygusunu geride bırakabilmenin yolu, ilk nesneden uzaklaşıp başka insanlara ve ilgi çekici nesnelere kaçmaktır. Bebeklikte açığa çıkan haset ne denli büyük olursa, çocuğun yetişkinlik yıllarında içinde bulunduğu suçluluk duygusu da aynı oranda yüksek olacaktır. Bu da suçluluk duygusunu aşmayı beceremeyen bireyin haset besleyebileceği her türlü şeyden kaçmayı kendisine çözüm olarak sunmasını beraberinde getirir. Haset duygusunun bireyin dünyasında açtığı en büyük yara, benlik parçaları arasındaki bölünmeyi genişletmiş olmasıdır. Suçluluk duygusundan kaçmak, yalnızca kişinin bu boşluğu daha fazla genişletmesini sağlar.

Firar psikolojisi, kendisini en net şekilde eksiklik duygusu taşıyan kişilerin dünyasında gösterir. İlk defa Adler'in kullandığı bir kavram olan “eksiklik duygusu”yla duygu dünyası yara almış, iç dünyasındaki çatışmaların bir sonucu olarak yaşama cesareti azalmış bireylerin içinde bulunduğu durum tanımlanır. Eksiklik duygusu taşıyan bazı kişiler, bu ruh halinden kurtulabilmek için tersine yatırım yapmayı tercih eder ve "eksiksiz üstünlük" duygusuna kapılır. Eksiksiz üstünlük duygusunu taşıyan birey, diğer herkesten üstün olduğuna ve kimseyle empati yapması gerekmediğine inanma eğilimindedir. Bu psikolojideki kişiler, yalnızca kendilerine değer vererek başkalarının düşüncelerine kayıtsız kalır. Bu duygu aşırıya vardırıldığındaysa kişinin toplumla uyumsuzluk içerisine düşmesine kaçınılmaz şekilde sebep olur ve bireyin yalnızlaşmasına yol açar. Diğer herkesten üstün olduğuna kendisini bir defa inandırmış bir kişi, kendisine hak ettiği değeri göstermediğini düşündüğü herkesten kaçmaya başlar ve sonunda kendisine alternatif bir yaşantı inşa etmek zorunda kalır (Adler, 2018, s. 17-8).

Kişiler, genel olarak kendilerinin sağlıklı ve güçlü bir ruhsal yapıya sahip oldukları inancına sahiptir. Ancak kişiye dışarıdan yönelmiş beklenmedik bir saldırı, bireyin sandığı kadar güçlü olmadığını açığa çıkararak benin kırılgan bir yapıya bürünmesine sebep olur. Saldırı, fiziksel olabileceği gibi ruhsal da olabilir, ancak her durumda bireyin psikolojisini yaralayacak bir iz bırakır. Saldırıya uğramak, beklenmedik bir durumdur ve kişinin çok dar bir zamanda fazla sayıda kötü tecrübe yaşamasına sebep olur. Bunun sonucunda birey, kırılmış benliğini tamir edebilmek için hızlı karar vermek zorunda kalır. Bu da onları kolayca kaçışa sürükler. Bu tarz bir tecrübenin ardından firar psikolojisi içerisine girmiş bireyler, kendilerini kötü hissetmemek adına kaçtıkları yerin aslında bir zorunluluktan kaynaklanmadığına kendilerini ikna etmeye çalışır. Bu durumda bu yer, onların aslında başından beri ulaşmayı hedefledikleri bir konumdur. Bu ikna sürecini başarıyla tamamlayabilmek için bilinç, geçmişe dönük yeni bir anlatı inşa eder ve hafıza bu sürecin en güçlü aracı haline gelir. Geçmişin dağınık hatıraları, bu anlatıyı doğru kılabilmek için farklı bir bağlamda bir araya getirilir ve sonunda yeni bir gelecek tasavvuru ortaya çıkar. Bütün bu olup bitenlerin ardındaki gerçek amaçsa, kişinin kendisine yönelmiş bir tehdit unsuru olarak kabul ettiği gerçeklikten kaçmaktır.

Korku duyan insan kaçar. Bu basit gerçeklik, insan psikolojisi için önemli bir olgudur. Bu sebeple firar psikolojisinin önde gelen güdülerinden birisi korkudur. Korkan insan, kendisini diğer her şeyden soyutlamak ister. Korkunun kaynağı dış dünyadaki herhangi bir şey olabilir. Buna karşıt şekilde kişinin karmaşık iç dünyası da korkuyu tetikleyebilir. Sebep her ne olursa 
olsun, korkunun sonucu kendini soyutlamadır. Başkalarına karşı soğuk davranışlarda bulunmak, firari bireyin en belirgin kişilik özelliklerinden biridir. Soyutlanmış kişi, başkalarıyla ya çok az konuşur ya da hiç konuşmamayı tercih eder. Kişinin sahip olduğu soğuk tavırlar, en basit gündelik jestlerde bile kendisini gösterir. İnsanlar arasındaki düşmanlık duygularının yükselmesinde, korkunun sebep olduğu soyutlamanın önemli etkisi vardır. Korkan birey, herkesten ve her şeyden kaçmak ister, bunun sonucunda kaçınılmaz olarak firar psikolojisi içerisine sürüklenir.

Bireyin kaçışı, yalnızca psikolojik durumu incelenerek anlaşılabilecek bir olgu değildir; meselenin sosyolojik bir boyutu da vardır. Kişiyi firara sürükleyen şeylerin temelinde, içinde yaşadığ 1 toplumla kurmuş olduğu karşılıklı ilişki de önemli bir yere sahiptir. Toplum, bireyden her zaman için kendisine uymasını bekler. İktidar, kişiyi çocukluktan itibaren öz benliğinden koparır, kendi organize ettiği okula gönderir, ödül ve ceza ikilemiyle disipline eder, sınava sokar ve sonunda onu ekonomik düzenin uysal bir parçası haline getirir. Modern dönemin iktidarının inşa ettiği bu yapıya uyum sağlamayanların, toplumun bütünlüğünü bozanların bu düzende yeri yoktur. Bu sebeple bütün farklılıklar temizlenir: Hastalar kliniğe, deliler akıl hastanesine, mahkumlar cezaevine kapatılır. İktidar, oluşturmuş olduğu biyopolitikanın sonucunda kişiyi önce bireyselleştirir, sonra da kontrol altına alır. Bu "büyük kapatılma"nın asıl amacıysa, ruhun ve tavırların dönüşümünü sağlamaktır ve bu modern dönemde medeni yasalara girmeye başlar (Foucault, 2019, s. 193). Bu politikayla uyumsuzluk içerisine düşen birey, doğal olarak kendisini bir kaçış içerisinde bulur. İktidar baskısıyla ve toplum normlarıyla çatışma içerisine giren kişi, şimdi bir ikilemin içerisindedir: ya bu uyumsuzluğu yok sayarak topluma karışacak ve sonunda mutsuz olacak, ya da isyanını açıkça ortaya koyarak kaçınılmaz olanı yaşayacak ve diğerleri gibi kapatılıp gözlem altına alınacaktır. Firar, bu noktada devreye girer, birey psikolojik olarak itaatsizliği, ancak eylem olarak bütünleşmeyi tercih eder. Bedenen toplumun içerisinde yaşar ancak onun homojen yapısına karışmayı reddeder, kendi kurgusal evrenini yaratır.

Badiou etiği, topluluğun bir arada yaşamasını sağlayan araçların önde gelenlerinden birisi olarak görür. Etiğin temel prensibi, pratik yaşayışın "İyi”" tasarısı etrafında şekillenmesidir (Badiou, 2019, s. 17). Modern demokrasilerdeyse etik bu şekilde işlememektedir. Etik, artık neyin İyi olduğuyla değil, neyin Kötü olduğuyla ilgilenmektedir. İyi'nin ne olduğunda anlaşma sağlayabilmek zordur, ancak Kötü, tanımlaması her zaman daha kolay olan bir kavramdır. Bütün ideolojiler, insanların yaşamlarını nasıl yaşamaları gerektiğine dair bir çerçeve çizerek işe başlar ve toplum için neyin Kötü olduğunu ortaya koyar. Bir defa Kötü olarak kodlanmış bu davranış biçimlerinin yasaklanması, toplumun ilerleyişine engel kabul edildiği için meşru görülür. Bu sebeple bireyin, sınırları belirlenmiş olan bu etiğin dışında hareket etmesi kabul edilebilir bir davranış şekli olmaktan uzaklaşır. Yerleşik sistem, her durumda bireye sistemin onun için belirlediği görevi verir, müdahale edenle tabi olanın yer değiştirmesi olanaksızdır. Kendisini bu etik anlayışının içerisinde sıkışmış hisseden bireyin firardan başka bir kurtuluşu yoktur.

Canetti, önemli eseri Kitle ve İktidar'da kişinin kendisini bir topluluğa ait hissetme arzusunu açık bir şekilde ortaya koymuştur. Kitle, toplumu oluşturan temel yapılardan biridir. Kişinin 
bilinmeyene karşı duyduğu korku, onu kendisi gibi olan insanlarla bir araya getirir ve bu motivasyon kitleyi oluşturur. Kişi, kitle içerisinde erir ve kendisini güvende hisseder. Her şey yolunda ilerlediği zaman kitle, içerisindeki insanlara son derece güvenli bir konfor alanı sunar, bu haliyle kitle sarsılmazmış gibi algılanır. Ancak kitleye doğrudan yönelmiş bir tehdit, bu güven yanılsamasını ortadan kaldırır ve kitleyi paniğe sürükler. Kitle ne kadar büyükse, tehdidin yarattığı korku da o denli şiddetli hissedilir. Kitleye yönelmiş tehdit, kişiyi paniğe sürükler ve bu ona, kendi bireyselliğini anımsatır. Böyle bir anda birey, kendi kurtuluşunun kitleyi terk etmekte olduğunu fark eder (Canetti, 2019, s. 26). Kitlenin önemi geride kalmıştır, artık önemli olan tek şey bireyin kendi hayatıdır. Tehdit anı, bireyin kitleden kaçmaya karar verme sürecini başlatır. Kaçışı gerçekleştirebilmek için bireyin aynı zamanda kendi kitlesiyle de mücadele etmesi gerekir, kitlenin dağılmış yapısı onu da peşinden sürüklemeye çalışır ve eğer kişi bu yapıdan kaçamazsa kitlenin kaderiyle aynı akıbeti paylaşmak zorunda kalır.

Mekân, firar psikolojisi içerisindeki kişinin sığındığ düzlem olması açısından çok önemlidir. Topluluktan kaçan birey, mekânda saklanır. "'Yeniden kabuğunun içine giren varlık', bir 'çıkış' hazırlar," (Bachelard, 2018, s. 146) diyen Bachelard, saklanan kişinin, yeniden açığa çıkacağı ana dek içinde bulunduğu ortamdan kaçtığına dikkati çeker. Kişinin doğuşu, beraberinde dış dünyaya karşı bir kabuk yaratır. Bu kabuk, onun dışarıdan gelebilecek saldırılara karşı oluşturduğu savunma kalkanıdır. Kişinin sırlarını ve iç dünyasını açıkça paylaşması, zayıf yönlerini de açığa çıkarması anlamına gelir. Bu yüzden her kişinin başkalarına karşı sahip olduğu bir mesafe mevcuttur. Ev, Bachelard'a göre, soyut kabuklara karşılık, kişinin somut dünyadaki diğer kişilere karşı sahip olduğu en güçlü sığınaktır. Eve dönüş, dış dünyadan kaçış anlamına gelir. İç dünyayla kurulan daha güçlü bir ilişki, kişiye dilediği gibi kurgulayabileceği sonsuz bir evren sunar. Firari birey, sahip olduğu hareketsizlik içerisinde istediği yöne hareket etme serbestisine sahiptir; onun en büyük özgürlüğ̈̈ budur.

Yukarıda açıklamaya çalıştığımız gibi kaçış arzusu, insanın en temel güdülerinden biridir. Ana malzemesi insan olan edebiyatınsa bireyin içinde bulunduğu firar psikolojisini görmezden gelmesini beklemek düşünülemez. Her türden edebi metinde, bireyin kaçış arzusu kendisine yer bulmuştur. Modern Türk edebiyatı da firar psikolojisinin metnin merkezinde olduğu metinlerle doludur. Öyle ki, bu metinler başlı başına bir edebi eğilim meydana getirir. Modern Türk edebiyatının en önde gelen isimlerinden birisi olan Bilge Karasu da bu eğilimin en dikkat çeken figürlerinden biridir. Ancak Bilge Karasu'nun metinlerini bu bağlamda incelemeye geçmeden önce, Modern Türk edebiyatındaki firar eğilimini ele almak, yazarın bu çizginin neresinde konumlandığını anlamak açısından önem taşır.

\section{Modern Türk Edebiyatında Firar Olgusu}

Modern Türk edebiyatı, başından itibaren iki yazar tipinin çatışması altında gelişme göstermiştir. Aydın yazar tipi, edebiyatı çoğu defa bir araç olarak kabul eder ve onu ideolojik bir aygıt olarak kullanır. Onun için edebiyatın özerkliği kavramı, metinleri araçsallaştırmasının önüne geçtiği oranda karşı çıkılması gereken bir görüştür. Aydın yazarın edebiyat ve birey 
ilişkisi de bu perspektifle ele alınır. Birey, bu tip yazarların eserlerinde toplumun içerisinde eriyerek özgül yanlarını kaybeder. Ondan farklılıklarını törpülemesi ve topluma uyum sağlaması beklenir, edebi metinlerde de bunu başarabildiği oranda takdir görür. Buna karşılık yenilikçi yazar her şeyden önce bireyi önceler, metinlerin merkezinde toplumsal meseleler değil bireyin sorunları, yaşam pratikleri, iç dünyası, kaygıları ve umutları yer alır. Bireyin merkezde oluşu, yenilikçi yazarların güncelle ilişkisinin kopuk olduğu ya da içinde yaşadığı topluma sırt çevirdiği anlamına gelmez. Bireyin dünyası, toplumun içinde bulunduğu durumdan ve döneminin ruh halinden doğrudan etkilendiği için, bireyi anlatmak, dolaylı yoldan daha büyük meseleler hakkında bir şeyler söylemektir. Toplum bireylerden oluşur, bu sebeple varoluş sancısı çeken, kendisini yalnız hisseden, modern dünyanın çaresiz ve kopuk bireyinin sorunları, gerçekte toplumun da sorunudur. Bu bakımdan yenilikçi yazarlar, konuda ya da biçimde yaptıkları bütün arayışlara rağmen, yaşadıkları dönemin gerçekliğini metinlerine taşıdıkları için aslında son derece "gerçekçi” bir edebiyat yapmaktadır. Ancak aydın yazarlar, alışılageldik beğenilerinin dışındaki bu yeni tarz edebiyatı anlamlandırmakta zorluk yaşar ve bu metinleri çözmek yerine onları faydasız, bireyci metinler olarak sınıflayarak kestirmeci bir tutum takınır. Bu durumun kaçınılmaz sonucu, yenilikçi yazarların edebiyat ortamının dışına itilmesidir. Tanpınar'ın “eksik sanatçılar" olarak nitelendirdiği bu kırgın yazarlar, her yerden dışlanmalarının sonucunda başkalaşım yaşar. Jale Parla'ya göre sanatçının sanatını taze tutmasının yolu başkalaşmasından geçer, bu nedenle başkalaşım süreci bütünüyle olumsuz bir durum değildir. Tam tersine, başkalaşmayı göze alamayan bir sanatçı başkalaşmış nesneler arasında silikleşir (Parla, 2018, s. 111). Başkalaşmış yazarın toplumla arasındaki mesafe, zamanla daha fazla genişler. Toplumdan kaçan yazarın sığınabildiği yegâne limansa edebiyattır. Konuşması engellenen ya da ciddiye alınmayan firari yazarın kendisini özgürce ifade edebileceği tek yer olan edebiyat, yazarın kaçışından büyük izler taşır. Firari yazar, metinlerinde de kendisi gibi firari karakterleri anlatmayı tercih eder. Bu tarz metinlerde okurun karşısına farklı rollerde çıkan karakterlerin ortak noktası, hepsinin içinde bulunduğu firar psikolojisidir. Kaçış arzusunda olan karakterleri merkezine almış metinler, modern Türk edebiyatında başlı başına bir firari yazın eğilimi ortaya çıkarır. Bu nedenle modern Türk edebiyatı, firari karakterler bakımından göz doldurucu bir koleksiyona sahiptir.

Beşir Fuad, modern Türk edebiyatının ilk firari figürüdür. Beşir Fuad'ın yaşantısıyla edebiyata bakışı, başlı başına bulunduğu toplumdan kaçış içerisinde olan ve bunu intiharıyla gerçekleştiren bir sanatçı portresi çizer. Pozitivizm ve natüralizm gibi akımları Türk edebiyatıyla tanıştırmış olan ve Victor Hugo tipi bir romantizmin Türk edebiyatında hakimiyet kurmasına karşı çıkan Beşir Fuad, edebi eserin değerini gerçeğe uygunluğuyla ölçme taraftarı olmuştur. Beşir Fuad, bütünüyle Batılılaşmış bir figürdür, doğuyu tümüyle reddedip batı felsefesini ve düşünce dünyasını Osmanlı İmparatorluğu'na hâkim kılmak ister. Dine bakışı olumsuzdur, Tanrı inancı bilinmese de herhangi bir dine inanmadığı ortadadır. Bu gibi kişilik özellikleriyle Beşir Fuad, yaşadığı toplumun bütünüyle dışında bir figürdür. Yaşadığı toplumla arasındaki bu büyük uçurumun onu toplumdan uzaklaşmaya itmemesiyse elbette düşünülemez. İçinde bulunduğu firar psikolojisi onu önce hedonist bir yaşantıya sürüklemiş, ardından intihar etmesine sebep 
olmuştur. İntiharı sırasında dahi yaşadığı tecrübeyi not edecek kadar pozitivizme iman etmiş bir figür olan Beşir Fuad, modern Türk edebiyatındaki firari eğilimin başlangıcını oluşturur demek yanlış olmayacaktır.

Beşir Fuad'da firar, sanatçının yaşantısıyla sınırlıdır. Firarın sanatçıların psikolojik dünyasında etkili olmakla birlikte metinlerinin de merkezine yerleştiği ilk dönem, Servet-i Fünun kuşağıdır. Yeni bir edebiyat anlayışıyla bir araya gelen Servet-i Fünun kuşağı yazarları, Abdülhamid yönetiminin sert ve katı tutumuyla dönemin kasvetli havasından bunalmış ve gerçek yaşamdaki durumdan kurtuluşu edebiyatın şefkatine kaçmakta bulmuştur. Kaçış arzusu Servet-i Fünun sanatçılarının düşünce dünyalarının merkezinde yer alır. Yurtdışına kaçmaktan Manisa'da bir çiftliğe taşınmaya kadar türlü arayışlarda bulunan dönemin sanatçıları, bunların hiçbiri gerçeğe dönüşmese de firar fikrini genel bir ruh hali olarak ömürleri boyunca taşımıştır. Servet-i Fünun kuşağının sembol isimlerinden Fikret, İstanbul'un kasvetli havasından bunalarak Boğaz'ın sakin dünyasına sığınmış, Aşiyan adını verdiği evinde gönüllü bir sürgün hayatına çekilmiştir. Burası, Fikret'in gündelik hayatın sorunlarından kaçmak isteyen dostlarının hizmetine sunduğu bir "güvenli bölge" olarak öne çıkar. Kaçış düşüncesini hayatı boyunca sürdüren Fikret, şiirlerinin merkezine de firar temini yerleştirir. "Yeşil Yurt”, "Ömr-i Muhayyel”, "Bir Mersiye”, "Sühâ ve Pervîn" gibi şiirlerinde firarın çeşitli boyutlarını ele alır. Döneminin insanı olan Tevfik Fikret'in içinde bulunduğu firar psikolojisi, Edebiyat-1 Cedide neslinin de ortak psikolojisidir.

Bu kuşağın romandaki en başarılı temsilcisi olan Halit Ziya, Mai ve Siyah romanıyla Türk edebiyatındaki en başarılı firari karakterlerden birisini yaratır: Ahmet Cemil. Tanpınar'ın "nesli namına konuşan ilk eser" dediği Mai ve Siyah'da "mavi hayaller, siyah gerçeklerle çarpışır" ve sonunda acı verici gerçeklik galebe çalar. Sanatçı olma arzusuyla yanıp tutuşan Ahmet Cemil, içine doğduğu koşulları aşamayarak kaderini eline almayı başaramaz ve hayallerinin sona erdiğini görür. Oysa Ahmet Cemil'in bütün hayatı gerçekliğin acı verici soğukluğundan sanatın haz verici sıcaklığına kaçmak, edebiyata sığınmaktır. Gençlik yılları içinde bulunduğu gerçeklikten kaçmakla geçen Ahmet Cemil, babasının ölümüyle birlikte ailesinin sorumluluğunu üstlenmek zorunda kalır ve artık onun için ikili bir hayat başlar. İş hayatının zorluklarını, sanatın hazzıyla dengeler. Bu bakımdan Mai ve Siyah, tam anlamıla bir künstlerroman'dır. ${ }^{1}$ Matbaa sahibi olmak için evlendirdiği kız kardeşi İkbal'in ölümü ve hoşlandığı Lamia'yı elde edemeyecek olmanın mutsuzluğu, yazdığg şiirlerin kendisini beklediği başarıya taşıyamamasının da etkisiyle birleşince Ahmet Cemil, derin bir karamsarlığa kapılır. Artık bu hayatta yapacak daha iyi bir şeyi yoktur, o da çözümü annesiyle birlikte İstanbul'dan uzaklara kaçmakta bulur.

Mai ve Siyah'ın en büyük başarısı, firari karakteri Ahmet Cemil'in şahsında dönemin Osmanlı aydınlarının içinde bulunduğu firar psikolojisini çok iyi tespit etmesidir. Modernleşmenin sancılarını yaşayan asır sonu Osmanlı'sında geçen bir hikâye olarak Mai ve Siyah, dönemin yeni insan tipini başarıyla ortaya koymuş ve bu döneme sirayet etmiş olan kaçış arzusunun ağırlı̆̆ını okuyucuya göstermiştir.

1 Künstlerroman: Sanatçı romanı. Sanatçı olmak isteyen bir kişinin gençlik ve çıraklık yıllarında yaşadığg sorunları ve sanatın güzellik ve çirkinliklerini anlatan romanlar. 
Türk edebiyatındaki firari eğilim, yirminci yüzyılda Ahmet Haşim’in şiiriyle başlar. Fecr-i Ati'nin tek temsilcisi olarak Ahmet Haşim, döneminin Milli Edebiyat akımının dışında kalmayı başarmış ve sanatı "şahsi ve muhterem" görmüştür. Firar, Haşim’in hem şiirinin hem de yaşantısının merkezindedir. Çocukluğunun aile ortamı Haşim'in yaşamında derin izler bırakmış ve bu durum onun içe kapanık bir kişi olmasına sebep olmuştur. Babasının sertliğinden annesinin şefkatine sığınmıştır, ancak annenin erken ölümü Haşim’i duygusal açıdan bir başına bırakmış ve bunun sonucunda Haşim kendisini her şeyden soyutlayarak firar psikolojisine bürünmüştür. Haşim'in şiiri de gündelik olana kapalıdır. Haşim'in şiirinde kaçış arzusu, devamlı merkezi bir yer tutar. Ahmet Haşim'in sanat anlayışında geçici olan şeylerden, değersiz hislerden, plastik imajlardan sürekli bir kaçış vardır. O, şiirde, kalıcı olanın, anlam taşıyanın ve en önemlisi kişisel olanın peşine düşmüştür. Bunu başarmak içinse şiirinde sembollere ve kapalı bir anlatıma yaslanır. Şiir, Haşim’e göre bir şeyi doğrudan anlatmaz, bunun yerine müphem bir şeyleri okura sezdirmeye çalışmalıdır. Kaçış arzusu, Haşim’in şiirinde belirli imgelerin arkasından kendisini belli eder. Akşam, günün 1şı̆̆ını sona erdiren bir imgedir ve bir müphemiyet yaratır. Bu da firar arzusunu her defasında tekrardan akla getirmiş olur. Haşim'in "Şi'r-i Kamer”lerinin merkezinde firar olgusu vardır. "Zulmet”, "Yollar” ya da "O Belde" gibi en bilinen bazı şiirlerinin merkezinde de açık bir firar anlatısı mevcuttur. Ancak Haşim bu kaçışta çoğunlukla başarısızlığa uğrayacağı düşüncesindedir. Kendisinin de çok iyi bildiği gibi hep aradığı "o belde" aslında bir hülyadan ibarettir. Oraya ulaşamamanın acısını ömrü boyunca hissedecek, ancak bunun hayalini kurmaktan yine de vazgeçmeyecektir. Kaçış, Haşim'de hiçbir zaman denenmeyen ancak hep arzu edilen bir olgudur ve bu açıdan Haşim'i statik bir yaşantıya sürüklemiştir.

Haşim'in edebiyat dünyasındaki aktif konumunun ortadan kalkmasının ardından Modern Türk edebiyatında firar eğilimi bir süreliğine gözden kaybolur. Savaş sonrası dönemde Osmanlı Devleti yıkılmış, yerine Türkiye Cumhuriyeti kurulmuştur ve yeni devlet, başka pek çok alanda olduğu gibi edebiyata da özerk bir alana sahip olma imkânı tanımamaktadır. Edebiyat, bu dönemde Kemalist ideolojinin dümen suyuna girer ve cumhuriyetin ilk yıllarında cumhuriyet ideallerinin halka benimsetilmesi yolunda ideolojik bir araç olarak kullanılır. Aydın yazarlar, bu dönemde yenilikçi yazarlara üstünlük kurmanın tadını çıkarır. Ancak İkinci Dünya Savaşı’nın ardından durum değişmeye başlar. 1950'li yıllarda edebiyat, yeniden özerkliğini ilan eder ve yenilikçi yazarlar, Türk edebiyatında baskın bir konuma erişir. 1950 kuşağı öykücüleri modernist bir öykü anlayışını inşa ederken şiirde de İkinci Yeni ilk defa özerk şiiri inşa eder. 1950'li yılların hareketli ortamında yetişen yenilikçi yazarlar kuşağı için en değerli şey, "üslupta kişisel özgürlük”tür (Dirlikyapan, 2017, s. 30). 50'li yıllarla birlikte bireyin dünyası daha önce hiç olmadığı kadar parçalanır ve varoluşsal sancılar görünür hale gelir. Toplumla uyuşmazlık içerisine girmiş bireyler doğal olarak sanatı da bu yönde dönüştürür ve hem biçimde hem de içerikte önemli değişikliklerin ateşleyicisi olur. Dönemin kaçak insanları hem o dönemde yazılmış öykülerde hem de İkinci Yeni’nin başı çektiği modernist şiirde merkezi bir konum elde eder. Modern Türk edebiyatında, İkinci Yeni'yle birlikte ilk kez politik olandan bilinçli şekilde uzak durulur ve şiir özerk bir alan kazanır (Armağan, 2017, s. 138-42). Vüsat O. Bener, 
Nezihe Meriç, Ferit Edgü, Erdal Öz, Onat Kutlar, Leylâ Erbil gibi isimler öyküde, Cemal Süreya, Turgut Uyar, Edip Cansever, Ece Ayhan, İlhan Berk, Sezai Karakoç, Ülkü Tamer gibi isimler şiirde firar psikolojisi içinde bulunan bireyi metinlerinin merkezine almış ve Modern Türk edebiyatındaki firari eğilimi sürdürmüştür.

Firari karakterlerin varlığı, romanda da kendisini göstermeyi sürdürür. Aylak Adam romanı, firar anlatısının önde gelen metinlerinden biridir. Halit Ziya'nın Ahmet Cemil'inin bıraktığı yerden, Yusuf Atılgan'ın Bay C.'si devam eder. Ancak Ahmet Cemil'in aksine, Bay C.'nin geçimini sağlamak gibi bir derdi yoktur. Ahmet Cemil'in firarı, sorumluluklarının ağırlığını taşıyamamaktan kaynaklanırken, Bay C. hiçbir sorumluluğa sahip olmamanın sıkıntısıyla firari bir kişiye dönüşür. Bay C., maddi gücü yerinde, varlıklı bir insandır, buna rağmen yaşamına anlam katan o içsel duyguya sahip değildir. Çocukluğu da sorunlu geçmiştir, babasıyla olan problemli ilişkisi kişiliğinde derin yarılmalara sebep olur. Bu nedenle Bay C. yetişkin hayatında çocukluk döneminin hatıralarını yadsıyarak kendi savunma duvarını örmüştür. Vaktinin çoğunu “aylaklık” yaparak geçiren, kafelerde, barlarda, restoranlarda vakit öldüren Bay C.'nin en çok yaptığg şeyler uzun yürüyüşler yapmak ve sürekli bir şeyler hakkında düşünmektir. Toplumla uyumsuzluk içerisinde olan C.'nin bu yürüyüşleri, onun kaçış arzusunu açığa çıkarır. Entelektüel bir kişilik olarak Bay C., toplumun kendisini boğduğunu hisseder ve onu ardında bırakmaya çabalar, ancak bir yandan da kaçınılmaz şekilde topluma bağımlıdır ve hayatını onun içerisinde sürdürmek zorunluluğunu taşır. Bu iki zıt durum arasında bulunmaktan dolayı psikolojik olarak yıpranan Bay C.'nin içinde bulunduğu firar duygusu bu açıdan bakıldığında anlam kazanır. Hayattan keyif alabilmek için bir tutamak arayışında olan C., aradığı şeye hiçbir zaman kavuşamadığı gibi, yazgısı olan firari olma halini de roman boyunca sürdürür. Onun için topluluğun içinde eriyerek kendi benliğini yitirmektense iç dünyasının çatışmalarıyla baş başa kalmak daha tercih edilir bir davranıştır. Küçük itaatsizliklerle kaçış arzusunu tatmin etmeye çalışır. Ancak C.'nin kaçışı kaçınılmaz olarak hiçbir yere varmayacaktır, C. kendisini bir şekilde hep kaçmak istediği toplumun ortasında bulur.

Yusuf Atılgan'ın tutamak arayışındaki firari karakteri C.'yi takip eden Tutunamayanlar'da Oğuz Atay, Modern Türk edebiyatındaki firar anlatısının en başarılı karakterlerinden birisini resmeder. C. ile Atay’ın karakterlerinin arasındaki temel farkı, kişilerin üstlendikleri “aydın olma" misyonu meydana getirir. C. entelektüel bir birikime sahip olsa da kendisini aydın olarak tanımlayan bir kişi değildir ve topluma yol gösterme arzusu taşımaz. Selim Işık’sa aydın bir karakterdir, ancak içinde yaşadığ 1 toplumla çatışma içerisine girmiş, küçük burjuva ahlakından kurtulamamış ve bu sebeple “tutunamayan” bir profil çizer. Oğuz Atay’ın yaşantısından bolca izler taşıyan romanda Selim Işık’ın yaşadığı dönüşümler, yazarın yaşamını birebir takip etmektedir (Ecevit, 2017, s. 162). Bir kez daha firari yazarla firari karakter aynı metinde bir araya gelmiş olur. Selim Işık, başlangıçta ülküleri olan bir karakterdir, yaşadığı ülkenin sorunları üzerine kafa yorar ve bunları düzeltmek için çareler aramaya başlar. Ancak onun bu naif çabası, yozlaşmış sistem ve toplumsal yapı tarafından aşındırılır. Bir kez daha müphem yerli ve milli olma duvarıyla karşı karşıya kalır. Bu durum, onun kendisini her şeyden soyutlaması ve mücadeleyi bırakmasıyla sonuçlanır. Yaşadığı hüsran, Selim Işık’1 giderek içe kapatır ve 
bu sonunda karakterin intiharıyla sonuçlanacak bir sürecin başlangıcı olur. Toplumdan kaçış, ideallerini geride bırakma, bunalım durumu Selim Işık’ın içinde bulunduğu firar psikolojisini gösteren önemli detaylardır. Tıpkı karakterleri gibi kendisi de yaşadığı toplumla çatışma içine girmiş bir kişi olan Oğuz Atay, kendi sorunlarından kaçabilmek için edebiyata sığınır. Oğuz Atay’ın karakterlerinin sonunda kaçınılmaz olarak intihara sürüklenmesi manidardır. Oğuz Atay, karakterlerini öldürerek kendi içindeki idealist kimlikten de kaçmanın yollarını aramaktadır. Oğuz Atay, Tutunamayanlar'la birlikte yaşadığı dönemin gerçek firari karakterlerini büyük bir ustalıkla gözlemlemiş ve o kuşağın buhranını romana başarıyla yansıtmıştır. Mai ve Siyah'dan sonra bir kez daha bir roman, nesli namına bu kadar önemli bir sözcü olma konumuna gelir. Dönemin baskısından bunalmış, toplumla arasındaki bağ zayıflamış, firar psikolojisi içerisindeki aydınlar Selim Işık’ta kendi “tutunamayışlarını” görmüştür.

Modern Türk Edebiyatındaki firari eğilim, gözden kaçmış olsa da önemli bir edebi çizgi meydana getirir. Özellikle yenilikçi yazar ve şairlerin eserlerinde merkezi bir yeri olan firar temi, yukarıda genel bir çerçevesini vermeye çalıştığımız çizgide gelişerek Modern Türk edebiyatının ilgilendiği temel meselelerden biri haline gelmiştir. Firari bireyin durumu, bu metinlerin öncelikli problematiklerinden birisi olarak kendisini farklı şekillerde gösterir. Firari yazarlar, içinde bulundukları psikolojiyi metinlerine yansıtır ve bireyin kaçış arzusu, bu tarz metinler aracılığıyla üzerine düşünülen bir konu olur. Ancak bu konuyla ilgili dikkat edilmesi gereken bir husus, firar psikolojisini metnin merkezine almış edebi ürünlerin kaçış edebiyatı olarak değerlendirilmesinin yanlış olduğudur. Başı başına bir alt başlık olarak kaçış edebiyatı, bizim burada genel bir resmini çizmeye çalıştığımız firari eğilimle karıştırılmaya müsait bir yapıda olsa da farklı motivasyonlardan beslenir. Kaçış arzusunda olan bireyi merkeze alan metinler, bu konuyu sorun haline getirerek bizzat meselenin üzerine gitmeyi tercih eder. Edebiyat, bu şekliyle sorunlardan kaçmanın değil, bizatihi sorunu anlamlandırmanın aracı haline gelir. Bilge Karasu, firari bir yazar olarak bu çizginin en önde gelen temsilcilerinden birisidir. Aykırı bir edebiyat anlayışı olsa da Karasu, firarı edebiyatının merkezine almasıyla bu eğilimin bir temsilcisi haline gelir. Bilge Karasu'da firar, yapıtın bütününü kapsar. Kendi yaşantısında da firar psikolojisi içerisinde olan Bilge Karasu' da yapıt ile gerçek hayat birbirini tamamlayan iki unsurdur. Onun edebiyatını firar psikolojisi bağlamında ele almak, bu nedenle anlam açısından kapalı metinlerinin aydınlanmasında faydalı bir çaba olacaktır.

\section{Bilge Karasu'nun Metinlerinde Firar Psikolojisi ve Bireyin Durumu}

Bilge Karasu, edebiyata bakışıyla hayatı arasındaki ilişkiyi, Mustafa Arslantunalı'ya verdiği röportajda şu şekilde ifade etmiştir:

"Kendim olmak diye bir kaygım yok galiba. İşte nasıl yazıyorsam öyleyimdir diyorum herhalde. (...) Nasıl tasarlıyorsam, nasıl yazıyorsam öyle oluyor. Kendim olmak, başka bir şey değil ki, çünkü onun dışında, onun ötesinde bir kendimlik yok ki, kendimlik burada söylediğimde, yazdığımda, yaptığımda.” (Karasu, 2017, s. 32) 
Karasu'nun da belirttiği üzere, onun sanatı yaşamına son derece paralel şekilde ilerler. "Nasıl yazıyorsa öyle" olduğu doğrudur, metinlerinin kapalılığı, onun hayata karşı aldığı ketum tutumun bir yansımasıdır. Ancak yaşamla metin arasındaki uyum, Karasu'nun edebiyatında kendisini otobiyografik bir ağırlık noktası olarak hissettirmekten uzaktır. Karasu'nun hayatıyla metinleri arasındaki paralellik kendisini asıl olarak yaşantının birebir metne yansımasında değil, daha çok hayatı yaşayış şeklinin metinlerinin ortaya çıkış tarzını şekillendiriyor oluşundadır. Kendisini “psikiyatri yönünden ele alınırsa kapall, kabuğuna çekilmiş bir insan” (Karasu, 2017, s. 223) olarak tanımlayan Karasu'nun insanlarla arasına koyduğu bilinçli mesafe, onun yaşayışıyla ilgili önemli ipuçları barındırır. Kadınlarla çevrili bir ailede büyüdükten sonra yetişkinliğinde ailesiyle arasına mesafe koymuş, felsefe eğitimi almış, musikiye meraklı, multilingual bir kişi olan Karasu, alışılmışın dışında bir profil çizmektedir. Sıtkı Erinç, Bilge Karasu'nun kalabalıklardan çekindiğini ve kalabalık ortamlarda konuşmaktan ziyade ikili ilişkileri önemsediğini belirtir. Adler'in gösterdiği üzere firari bireyler topluluk içerisinde konuşmaktan çekinir, bunun yerine dostlarıyla baş başa konuşmayı tercih eder. Karasu, yaşamı boyunca bu tutumunu sürdürür ve özel dostluk ilişkilerini olabildiğince dar bir alanda tutmaya çalışır. Karasu'nun bir diğer öne çıkan özelliği, seyahat etmekten çok hoşlanması ve kentte bunaldığını hissettikçe seyahat etmesidir. Karasu'nun seyahat tutkusunda bu yolla zihnini taze tutmak istemesinin olduğu gibi kalabalıklardan kaçma arzusunun da izlerini görmek mümkündür. İntiharsa, yazarı özellikle gençlik yıllarında çokça düşündürmüş bir olgudur. İntihar etmeyi birkaç defa ciddi düzeyde düşünür, ancak "yaşamı daha ilginç bularak" bu fikirden vazgeçer. Ancak yine de intihar düşüncesi yazarın zihninden bütünüyle kopmaz ve yıllar içerisinde ara ara aklına gelen bir düşünce olarak kendisini hatırlatır. Modern Türk edebiyatının ilk firari figürü Beşir Fuad' da olduğu gibi, Bilge Karasu da içinde bulunduğu buhrandan çıkışı intiharda görür. Ancak Fuad'ın tamamladığı intiharı gerçekleştirmekten vazgeçer. Yine de bir kaçış arzusu olarak intihar fikri üzerine sorgulamayı sürdürecektir. Bilge Karasu’nun cinsel yönelimi de onu sorun yaşamamak için kaçınılmaz olarak kimliğini gizlemeye yöneltmiştir. Karasu, toplumsal normların dayattığı saygınlık duygusunu koruyabilmek için, "birtakım şeylerin yapılmaması, birtakım yerlere gidilmemesi” gerektiği fikrindedir. Karasu'nun kurgu dişı metinlerinden öğrendiğimize göre, kimliğinin getirisi olarak davranışlarının temelinde gizlenme güdüsünün olduğunu ifade eder. "Ne olduğunu göstermemek," Karasu için dikkat edilmesi gereken bir kaygıdır. Cinsel yönelimi yüzünden karşı karşıya kalabileceği problemlerden sıyrılabilmek adına cinsel kimliğini yakın çevresi dışında gizlemeyi yaşamı boyunca sürdürmüş, bu kaçış onu hayatı boyunca takip etmiştir. Tüm bunların yanında Musevi bir aileden geliyor oluşu da onun Türkiye toplumu için iyice aykırı bir birey haline gelmesine zemin hazırlar. Türkiye'de yaşayan bir azınlık olarak, diğer kişisel özellikleriyle birlikte devletin ve toplumun çizdiği "makbul vatandaş" sınırlarının bütünüyle dışında kalır. Bütün bu unsurlar, bir araya gelerek Bilge Karasu'nun hayatı boyunca etkisini hissedeceği firar psikolojisi içerisine girmesine sebep olur.

Karasu'nun içinde bulunduğu firar psikolojisi, etkisini yazarın metinlerinde doğrudan gösterir. İlk öykülerinden son yazılarına dek edebi dünyası bu kaçış fikri üzerinde şekillenmiş, 
metinlerinde firar anlatısı merkezi bir yer teşkil etmiştir. Yayımlanmış ilk kitabı Troya'da Ölüm Vardl' da bu etki kendisini net şekilde hissettirir. Bu kitaptaki öykülerde yazar, çocukluğun dünyasını farklı bir yaklaşımla anlatmayı tercih eder. Hikayelerin paylaştığı ortak özellik, çocukluk döneminin masum yaşantısıyla büyümenin getirdiği sancıların ikiliği yüzünden acı çeken ve aynı dönemde kendi cinselliklerinin farkına varan çocukların, aileyle ve yaşadıkları toplumla yaşadıkları çatışma ve sorunlu ilişkilerdir. Troya'nın çocukları, çocukluklarında yaşadıkları Sarıkum'un sıkıcı ve boğucu atmosferinden kaçmak isterken, yetişkinliklerinde aynı köy onlara bu defa şehirden kurtuluş mekânı olarak gözükür. Sarıkum, bu öykülerin çocukları için daraltıcı bir yerdir. Ailelerinden gördükleri baskı ve sevgisizlik, annelerinden gördükleri aşırı ilgiyle birleşince kaçış arzusu dayanılmaz bir noktaya gelir. Ancak çocuk bedenleriyle Sarıkum'u terk etmeleri mümkün olmadığı için, boğucu dünyalarından kaçışı birbirlerine sığınmakta bulurlar. Öykülerde sürekli kendisini tekrar eden bir leitmotif olarak tren, olay örgüsünün gelişimi sırasında devamlı araya girerek akışı kesintiye uğratır ve karakterlere kaçış fikrini hatırlatır. Tren, Sarıkum'dan çıkıp şehre gitmenin, her şeyi arkada bırakıp köyü terk etmenin simgesi haline gelir. Çocukların, özellikle Müşfik ile Suat'ın yeni uyanmakta olan cinsellikleri de taşra yaşamını onlar için iyice boğucu hale getirir. Müşfik'le Suat arasındaki eşcinsel ilişki, hem durgun köy hayatından bir kaçış sunduğu için heyecan verici, hem de yakalanma riskinin yüksekliğiyle korkutucudur. Sarıkum'un çocukları arasındaki mikro iktidar ilişkileri de henüz yetişkinlik çağına erişmemiş bu çocukların psikolojisinde iz bırakacak tahribatlara yol açar. Sünnet, çocukluktan çıkıp erkekliğe erişme töreni olarak anlatıcıyla Fikret arasında bir gerilim yaratır (Karasu, 2019, s. 16). Fikret'in sünneti, anlatıcıya kendisini küçük bir çocuk gibi hissettirir. Çocukluk, bir an önce kurtulunması gereken bir dönemdir, bu çocuklar bir an önce yetişkinliğin dünyasına adım atmak ve kendi iktidarlarını kurmayı arzu eder. Müşfik'in “Odalardan Biri” öyküsünde evine dönmeyip geceyi bir otelde geçirmesi bu bakımdan son derece anlamlıdır. Müşfik evinde mutlu değildir ve oradan kaçmak ister. Bilinçli şekilde evinden uzakta durur, eve gitmek istemiyordur. Babası onu geç döndüğü başka bir gece de eve kabul etmemiş ve kapıyı sürgülemiştir. Eve gidip bakmış olmasa da yine aynı manzarayla karşılaşmaktan çekinir, halihazırda eve dönmeye karşı bir isteği de yoktur. Bu yüzden geceyi Sarıkum'un tek otelinde geçirir, kendisini evden koruyacak bir yere ihtiyacı vardır. Müşfik'in talep ettiği şey yalnızca bir "Oda"dır; bu oda isteği, otelde geçirmek için bir oda tutmanın yanı sıra, hayatının geri kalanını özgürce geçirebileceği bir yer talep etme anlamına da gelir. Evinden kaçıp dışarıda kaldığı bu ilk gece, onun yetişkin dünyasına adım attığı anlamına gelir. Troya'nın çocukları sevgisiz büyümüş, güdük, firari kişilerdir. Müşfik ve Suat'ın annelerinin aşırı düşkünlüğünden kaçması boşuna değildir. Gustav Jung'ın anne arketipine uygun olarak bu anneler hayattaki eksikliklerinin yerine çocuklarını ikame etmeye çalışır. Ancak onlara gösterdikleri aşırı ilgi ters tepki yaratır ve çocuklarının kendilerinden uzaklaşmalarına neden olur. Anneden kaçış, hem Suat'ın hem de Müşfik'in yaşamı boyunca sürdürecekleri bir tavır haline gelir. Yıılar sonra, Müşfik'in ailesiyle birlikte İstanbul'a taşınması beklenen değişikliğe yol açmayacaktır. Firari bir kişilik olan Müşfik, taşranın durağanlığından kaçmak istediği gibi şehrin karmaşasından da kurtulmak ister. Geçmişte kaçmak istediği Sarıkum, şimdi kendisini hatırlatan, nostaljik bir hayal haline gelir. Şurası açıktır ki kaçış hali onların ortak kaderidir ve 
bu durum onları yaşamları boyunca takip edecektir. Acı verici olansa, devamlı bir şeylerden kaçan bireyin asıl sorununun kendi psikolojisinde yatıyor oluşudur. Birey, ne kadar istese de kendisinden kaçamayacağı için, firar hali kaçınılmaz şekilde varlığını sürdürür. Ortada duran sorunu çözmeye çalışmaktansa onu yok saymak çok daha kolay bir çözüm gibi gözükür, ancak bastırılan her şey bir gün mutlaka geri dönecektir: bastırılan şey dönüşür ve bireyin psikolojisini bu defa daha sert vurur.

Uzun Sürmüş Bir Günün Akşamı'nda firar kendisini çok daha açık şekilde gösterir. Bu defa kaçış arzusu bireyin psikolojisinde kendiliğinden tetiklenen bir şey değildir; öykünün merkezinde kişinin inancına iktidar tarafından yöneltilmiş bir baskı ve bu baskıya karşı bireyin geliştirdiği bir savunma vardır. "Ada” ve "Tepe” öykülerinden meydana gelen "Uzun Sürmüş Bir Günün Akşamı”nda hikâye Bizans’taki ikonoklazm döneminde geçer. İktidarın dayattığ yeni yasa sonucunda kişilerin yüzleşmek zorunda kaldığı inanç değiştirme zorunluluğu, din düşüncesine dair bir sorguyu beraberinde getirir. Her zaman olduğu gibi, çoğunluk bu dayatma üzerinde çokça durmaz ve yeni inancı sorunsuzca kabul eder. Ancak çok az kişi bu tepeden inmeci dayatmaya karşı çıkmayı göze alır. İmparatorun yasasına karşı çıkmanın cezası çok açıktır, bu yüzden yeni inanca karşı çıkış, İmparatorluk başkentinden kaçma zorunluluğunu beraberinde getirir. “Ada” öyküsünün baş karakteri olan Andronikos, bu firari kişilerin öncüsü olarak ön plana çıkar.

Andronikos'un temel trajedisi, kahraman olmayı başaramamasının psikolojisinde yol açtığı tahribattır. İmparatorun getirdiği yeni inanca bağlanması mümkün değildir, çünkü buna kalben inanmamaktadır. Sorunsa, kendisinde bu inanca karşı çıkacak bir güç bulamadığı anda başlar. Yeni inanca karşılık eski inancı ne pahasına olursa olsun savunması gerektiğini düşünür, bunu yaptığı takdirde bir kahraman -ve belki de bir "inanç şehidi”- olacaktır. Ancak içine düştüğü sorgulama, Andronikos’un eski inanca da gerçekten bağlı olmadığını açığa çıkartır. Andronikos, ikonlara karşı gerçekten inandığı için ibadet etmemiştir, bunu sürdürmesi gerçekte yalnızca bir alışkanlıktan ibarettir. İçine düştüğü girdap, onun inançsızlığa sürükler. Bu durumda yapabileceği bir şey yoktur, elinden gelen tek şey başkenti terk etmektir. Bask1, “Uzun Sürmüş Bir Günün Akşamı”nın en genel çerçevesini çizer ve öykünün “tarihsel-olgusal arka planını” oluşturur (Akatlı ve Sökmen, 2019, s. 154). Baskı, kişinin dünyasına yönelir ve o güne dek oluşturduğu bütün değer dünyasını yok eder. Bu açıdan son derece olumsuz bir değere karşılık gelir. İktidar baskısı, Andronikos'u kaçışa sürükleyen temel etken olmuştur. Daha fazla kendisini ait hissetmediği bir dünyada yaşamayı sürdürmesi mümkün değildir, bu, en başta kendisine karşı yapacağı bir saygısızlık olur. Bu yüzden başkentten kaçacaktır, kendisini bu dünyaya bağlayan her şeyden firar eder. Kaçışında sığınacağ yerse kente yakın bir ada olacaktır. Adada kendisini sıfırdan inşa edilecek yeni bir dünya beklemektedir. Onun karşı karşıya olduğu zorluk da budur.

Yeni inancın norm haline gelişiyle birlikte Andronikos'u geçmiş yaşantısına dair en çok ürperten şey, hayatı boyunca bir yalanı yaşamış olma ihtimalidir. Yeni inancı kabul etmesi bu sebeple mümkün değildir, ancak eski inançta bağlılığın sonunun zindan olduğu da açıktır. 
Andronikos'a firarın yolunu açan şeyse, inancının aslında bir yalana dayandığını kendisine itiraf etmesi olur (Karasu, 2017, s. 38-9). Adaya sığınmasıyla birlikte, baskıdan kaçtığı için artık utanç duymamaya başlar. Korkmak son derece olağan bir durumdur ve bu durumda onun kimliğinin bir parçasıdır. Yine de kahraman olmayı başaramamış olmaktan rahatsızlık duyar. Yolculuk boyunca önüne bunu başarmak için çokça firsat geçse de hiçbirisini değerlendirememiştir. İnanca karşı çıkmayı başaramamış olması da onun bir kahraman olmadığının en açık delilidir. Andronikos, içinde bulunduğu durum itibariyle yalnızca bir "kaçak"tır ve bunun acısını çeker. Bununla birlikte, adada geçirdiği günlerin ardından başkente dönmeyi ve yeni inanca karşı çıkmayı göze alır. Onun bu dönüşü, yeniden inanmaya başladığı anlamına gelmez, o sonunda kahraman olmayı göze alabilmiştir. İnanmadığı bir şeyden korku duyup kaçmayı daha fazla kabul edememiştir. Bu hareketiyle birlikte sonunda kahraman olmanın yolu kendisine açılır. Andronikos, ölene dek konuşma cezasına çarptırılır, ancak onun göstermiş olduğu cesaret, geride kalan ancak ses çıkartmaktan korkan diğerlerine cesaret verir. Andronikos, onurunu korumuştur.

“Tepe”deyse bir başka kaçış vardır; firar eden bu defa Andronikos’un dostu İoakim'dir. Ancak ikisinin kaçışında belirgin bir fark gözlemlenir: Andronikos sonu kahramanlıkla bitecek bir başkaldırıyla kaçmıştır, İoakim'se hiçbir zaman kahraman olamayacağının bilinciyle firar eder. İoakim, yaşamı boyunca Andronikos'un kahramanlığg altında ezildiğini hisseder. Andronikos, yeni inanç duyurulduğu anda kenti terk etmiştir, kendisiyse her şeye rağmen başkentte kalmış ve inanmadığı halde yeni inanca uyum sağlamıştır. Bu, onu Andronikos karşısında korkak durumuna düşürür. $\mathrm{Bu}$, onun vicdanında iz bırakan bir yaraya dönüşür. Andronikos verilen ceza gereği ölene dek durmamacasına konuşurken, onu seyretme görevi İoakim'e verilmiştir. Bu, İoakim'e eğer yoldan çıkarsa başına neyin gelebileceğine dair verilmiş bir gözdağıdır. Bu ölüm, İoakim'e hiçbir zaman kahraman olamayacağı gerçeğini gösterir. İoakim’e göre böylesi bir ölüm anlamsızdır, Andronikos bir hiç uğruna ölmüştür. Yine de onun ölümünde son derece soylu bir taraf vardır ve İoakim bu ölümün ağırlığı tarafından ezilir.

Zaman, yeni inanca dair fisıltıların yayılmasını beraberinde getirir. Homurtular yükselmeye başladıkça, ikonoklazm'a karşı direniş güç kazanır. İoakim, bu noktada bir yol ayrımına gelir: Ya manastırda kalmaya devam edecek ve yeni inancın tarafinda kalacaktır, ya da isyancılarla birlikte başkenti terk edip eski inancın savunmasına katılacaktır. Ancak o bir üçüncü yolu tercih eder, şehirden kaçıp kendisini Ravenna'ya götürecek bir gemiye biner. Onun için anlamsız gelen bütün bu tartışmaların artık dışında kalmıştır. Ravenna'da eski inanca uygun şekilde inşa ettiği kiliseye kapanır ve yıllarını burada geçirir. Artık bütün dini ayinler anlamsızlaşmış, hayat değerini yitirmiştir. Bu yüzden, Bizans’ta resim yasağının kalktığı duyurulup eski inanca dönüş başladığında radikal bir hareket yaparak kilisesini Katolik kilisesine bağlar.

İoakim'in dramı arada kalmışlı̆̆ıdır. O baştan ayağa firari bir kişidir, hiçbir yere ait olmayan ve oradan oraya savrulan bir karakterdir. İoakim'i Bizans başkentinden kaçmaya sürükleyen motivasyon, yapabilecek hiçbir şeyin olmaması değildir. Onu firar etmeye zorlayan asıl sebep, İoakim'in hiçbir şey yapmak istememesidir. İoakim, Andronikos kadar cesur olamamış, kendisi 
kalabilmek uğruna ölmeyi değil, kendisini inkâr etme pahasına kaçmayı tercih etmiştir. Bilge Karasu, Uzun Sürmüş Bir Günün Akşamı'ndaki öykülerde merkeze “öteki”yi koyar. Andronikos ile İoakim, yaşadıkları şehirde hiç beklemedikleri bir anda kendilerini "öteki” konumunda buluverir. Kendi inançlarına yönelen bu tehdit anında firar etmekten başka yapabilecekleri bir şey yoktur. Andronikos, sonunda geriye dönerek kahraman olma yolculuğunda çemberi tamamlar. İoakim'se bir defa başladığı kaçışı sonuna dek götürerek onu kimliğinin ayrılmaz bir parçası haline getirir.

Göçmüş Kediler Bahçesi'nde Karasu, modern bireyin içinde bulunduğu kaçış arzusunu ustalıkla ele alır. Bu kitapta karşımıza çıkan metinler, eski bir edebi türde, masal türünde kaleme alınmıştır. Karasu, buradaki metinleri masal olarak tanımlayarak belirli bir türe sıkışmayı reddeder. Onun firarı, yalnızca içerikte değil, edebi metnin biçiminde yazara dayatılan tek tipleşmeye de karşıdır.

Eksiklik duygusu taşıyan birey, Alfred Adler'in psikolojisini ortaya koyduğu ve üzerine geniş çaplı çalışmalar yaptı̆̆ içerisindeki bireylerine birebir uyum gösterir. Göçmüş Kediler Bahçesi'ndeki masallarda hikayesi anlatılan bireyler, çoğu defa yaşadığı gerçeklikten tatmin olmayan, arayış içerisindeki eksiklik duygusu taşıyan kişilerdir. Eksikliği ortadan kaldırmak için bu kişilerin birbirlerine yaklaşması, bağlantı kurması gerekir. Ancak sorunları çözebilmek için birbirine yanaşan bu kişiler sonunda birbirlerine muhtaç hale gelir, bu ilişki dışındaki her şey yabancılaşır, bu ilişkiler "giderek başka ilişkileri olanaksız kılar." (Akatlı ve Sökmen, 2019, s. 193) Ölümse, bu masallarda kaçınılmaz son olarak ortaya çıkar. Birbirine bağımlı kılan bu ilişkiler, sonunda bireyleri kaçınılmaz şekilde ölüme sürükler. Firar, tam olarak bu eksik modern bireylerin içine düştüğü arayıştan ortaya çıkar. Kaybolmak, her şeyi geride bırakmak, kişinin kendisini keşfetmeye başlaması için birinci önceliktir. Firar psikolojisi içerisindeki bu bireyler yeni bir yolculuğa çıkmadan önce geçmişle olan ilişkilerini sona erdirir. Bu zorunludur; çünkü kişinin aradığını bulabilmesi için eski benliğinin “ölmesi” gerekir. Masallardaki ölüm bu sebeple yalnızca akla ilk gelen anlamıyla anlaşılmamalıdır. Ölüm, bireyin "yeniden doğuş” öncesi aşması gereken bir engeldir.

Göçmüş Kediler Bahçesi'nde dikkati çeken bir diğer husus, yazarın dil kullanımında gösterdiği hassasiyettir. Verili dille yetinmeyen Karasu, olağanüstü bir dünya kurgularken edebi dilini de buna uydurur. Karasu, buradaki masallarında dili olabildiğince ağırlaştırır. "Koyak", “söbe”, “kürtün”, “çıdam”, “ivecen”, “değirmi”, “küşün”, sofracı” gibi unutulmuş Öztürkçe kelimeleri bolca kullanırken "gelesiye”, "diyesiymiş" gibi deyişlerden faydalanmayı da ihmal etmez (Yaşat, 2017, s. 33). Karasu için okurun dil beklentisi önemli değildir, o, metninin gerektirdiği dili kullanmayı tercih eder. Bu tercihinin okumayı zorlaştırması onun için önemli değildir. Anlatmak istediği firari kişileri, ancak kendi kaçak diliyle anlattığı zaman başarıya ulaşabilir. Bu açıdan bakıldığında, metinlerdeki firar temi, biçimde ve dilde de kendisini göstererek bütüncül bir görünüm arz eder. 
Karasu'nun firari bireyleri, hayatla farklı açılardan dertleri olan kişilerdir. "Avından El Alan"ın avcısı, çocukluk yıllarının yalnızlığını ömrü boyunca hisseder. Bu durum, onun yetişkinliğe adım attığı zaman kırılgan bir yapıya bürünmesine neden olur. Başkalarıyla kolayca ilişki kuramayan avcının sevdiği tek şey, herkesten uzaklaşıp denize açılmaktır. Denizde kolunu ısıran orfinozla arasında başlayan simbiyotik ilişki, bu açıdan bakıldığında anlam kazanır. Yıllarca yalnız kaldıktan sonra, şimdi bu balıkla dostluk kurabilecektir. Ancak ikisinin ilişkisinde zamanla av ile avcı yer değiştirmeye başlar, orfinoz, varlığını her yönüyle avcıya dayatmaya başlar. Balıkla birlikte tamamlandığını düşünen avcı, orfinoz onu terk ettikten sonra yeniden eksik kaldığı duygusuna kapılır. Yeniden o birliğe erişmek için kendisini balığın ardından denize bırakır. Bu masal, modern bireyin önemli sorunlarından birisini gözler önüne serer: Modern birey, kendisini eksiksiz hissedebilmek için başka canlılara muhtaçtır.

“Geceden Geceye Arabayı Kaçıran Adam”ın karakteri, modern şehrin boğucu ortamından sıkılmıştır, yeniden doğaya dönmeyi arzu eder. Ancak ulaşmak istediği Sazandere, neredeyse ulaşılmaz bir yerdedir. Oraya giden hiçbir otobüs bulamamakta, oradan gelip giden kimseye rastlamamaktadır. Sazandere'ye gitme uğraşı, onun şehirden kaçış arzusunun somut bir hedefi haline gelir, ancak bu hedefe ulaşmak mümkün görünmemektedir. Garajda sıkışıp kalan bu adam, gerçekte kendi geçmişiyle geleceği arasında sıkışıp kalmıştır. Ne Sazandere'ye gidebilmekte ne de geriye dönebilmektedir. Sonunda Sazandere'ye ulaştığını sanırken, onu ücra bir yerde kendi yaşlılığı karşılar. "Korkusuz Kirpiye Övgü”de Karasu, kaçış arzusunu bu defa bir kirpinin alegorik hikayesiyle okuyucuya aktarır. Yıllarca dış dünyayı dolaşıp yeni şeyler keşfetmek isteyen kirpi, sorumlulukları yüzünden bunu gerçekleştirememiştir. Her şeyi geride bırakıp dünyayı keşfetmeye çıkmak en büyük arzusu olduğu halde bunun için uzun süre beklemesi gerekir. Sonunda annesini ziyaret etmek bahanesiyle de olsa sokağa çıkan kirpi, karşısında bambaşka bir dünya görür. Kirpinin başından geçenler, şu basit gerçekliği bir kez daha gözler önüne serer: kendini gerçekleştirebilmek için her şeyden kaçmak ve yeni şeyler deneyimlemek gerekir.

"Dehlizde Giden Adam" masalındaysa modern bireyin firarı açık bir şekilde sorun haline getirilir. Girmesi yasak olduğu halde inatla dehlize giren adam, çıkışa yaklaştıkça kör olacağ 1 bir mağarada hayatın anlamını arar. Mağarada ilerledikçe geçmiş yaşantısının yanılsamalarından koptuğunu fark eder, dehlizde her şey boyut değiştirmiş gibidir. Geçmiş yaşantısının gerçekliği artık ona tatmin edici görünmemeye başlar, bu sebeple mağaranın sonunda neyle karşılaşacağını merak ederek ilerlemeye devam eder. Sonunda dehlizden çıkmayı başardığındaysa kör olmuştur, bir kayanın üstüne oturarak ölümü bekler. Delikanlının mağaradaki arayışı, sonunda ölümle sonuçlanır. Ancak bu sembolik bir ölümdür, delikanlı mağaradan geçtiğinde eski dünyasından sıyrılarak yeni bir gerçekliğe adım atmış olur. Geçmişindeki yaşantısından kaçmıştır, yeni yaşamına uyum sağlamasıysa vakit alacaktır. Delikanlı, anlam bunalımındadır, bu bunalım onu mağaraya sürükler. Sonunda mağaradan çıktığındaysa bunalımını aşarak adeta yeniden doğar.

"İncitmebeni”, "herkesin, [...] giyinmek için uğraşıp didindiği bir dünyada, [...] soyunmaktan başka bir şey dilemeyen bir adamın masalı"dır (Karasu, 2017, s. 132). Bir öğretmen, yaşadığ 
yerdeki insanların kendi küçük sorunlarıyla ilgilenmekten hayatın anlamını sorgulamaya zaman ayıramadığını görür ve bireyi öğüten bu girdaptan kurtulabilmek için yaşadığı yerden kaçıp bir adaya sığınır. Geride bıraktığı şehir, çoğu kişinin yaşamak için çokça fedakarlıkta bulunabileceği bir yerdir. Ancak onun amacı daha fazla para kazanmak ya da başkaları üzerinde iktidar kurmak değildir. $\mathrm{O}$, hayatın özünü kavramak, bunun için kendi benliğinden "soyunmayı başarabileceği” bir ülkeye gitmek ister. Başlangıçta yeni yerleştiği bu adada mutludur, ancak adanın yerlilerinin bu yeni yabancıya karşı katı tutumları, onun burada da mutluluğa ulaşamayacağının habercisi gibidir. Adanın karşı karşıya olduğu bir felaket, bir anda bütün yaşamı alt üst eder. Ada, beklenmedik bir şekilde büyümeye başlamıştır. $\mathrm{Bu}$ beklenmedik yeni gelişme, adadaki herkesi birbirine düşürecektir. Adanın kötü bakışlarından kurtulmak için sahip olduğu tüm parayı toprağa gömen öğretmen, bu hareketiyle geçmişinden kaçmayı başarabildiğini ummuştur. Ancak yeni bir kriz anı, onun burada da aradığı huzura kavuşamayacağını gösterir. Üstelik bir yabancı olarak yerlilerin gözünü devamlı üzerinde hisseder. Gerçekte olan başarılmış bir firar değildir, adam yalnızca -miş gibi yaparak mutlu olabileceği yanılsamasına kapılmıştır.

Adanın büyümesi bir gün aniden durur. Bu defa tam tersi bir gelişme baş gösterir: Ada denize doğru batmaktadır. Bu nihai sondan bir kaçış yoktur, adalıların hayatları boyunca kaçmaya çalıştıkları kaderleri onları yakalamıştır. Ada sulara gömülürken, öğretmen suların üzerinde yüzen kendi paralarını görür. Aradığı özgürlüğe kavuşmak için paralardan kurtulması gerekmiştir, ancak o paraları gerçekten yok etmektense kumun altına gömmeyi tercih ederek kendisini kandırma yoluna gitmiştir. Şimdi, paraları geri dönüşü olmayacak şekilde suyun üzerinde yüzerken, yaşamı boyunca aradığı özgürlüğe ölümüyle birlikte kavuşmuş olur. Adada karşısına çıkan insanlarsa onun için gerçek bir hayal kırıklığı olmuştur. Buradaki insanların da küçük dünyalarının boğuculuğundan kaçtığı büyük şehrin insanlarından pek bir farkı yoktur. Öğretmen, içindeki eksiklik duygusunu gidermeyi başaramadan suların altına gömülür.

Yukarıda da değinmiş olduğumuz gibi, eksiklik duygusu içindeki modern bireyin firarı, Göçmüş Kediler Bahçesi'ndeki masalların neredeyse hepsinde ortak bir tema olarak okurun karşısına çıkar. Kişilerin eski benlerinden kaçarak yeni bir arayışa çıktığı yolculukların sonu genellikle ölüme çıkar. Ancak sanılanın aksine ölüm bu öykülerde korkulan bir son değildir, tam tersine, yeni bir başlangıca vesile olacağı için arzulanan bir şeydir. Firarı sonlandıran ölümdür, birey, öldükten sonra “yeniden doğar.” Bilge Karasu'nun intihar üzerine uzun zaman boyunca düşündüğü göz önüne alındığında, bu metinlerdeki ölümün onun bir türlü aşamadığı ölüm fikrine karşı yazıyla ödediği kefareti olduğu yorumu yapılabilir.

Bilge Karasu, Klsmet Büfesi'nde devamlı yaptığı türsel geçişlere bir yenisini ekler. Bu defa kendisini anlatmak için metin türünü kullanır. Ancak onun kaleme aldığı eserlerin belirli bir kalıba sokulacağını hissetmesi bile edebi bir tedirginlik hissetmesine yeterlidir. Bu sebeple buradaki yazılarına "metin" adını vermekte bile kararsızdır: 
“Bu kitaptaki yazılara, dergilerde yayımlanışları sırasında, 'metin' adını verirken, bunların herhangi bir türe girmediklerini, onları yazarken özgür kalmak istemiş olduğumu vurguluyordum. Yıllar sonra, 'metin'lerin bir tür oluşturmağa yüz tuttuğu bu sırada, kitabımın bir metinler kitabı olduğunu söylemekten vazgeçiyorum." (Karasu, 2016, s. 7)

Karasu, yazılarını belirli bir türle sınırlamaktan bir kez daha kaçmayı tercih etmiştir. Bu kaçış, ona türler arasında istediği gibi gezme ve anlatısını özgürce kurgulama imkânı sunar. Metinlerin özgür kalabilmek için yeniden verili olandan "kaçması", tanımsız bir tür haline gelmesi gerekir. Cem İleri, bu kaçış halini şu şekilde belirtir:

"Metinler bir kez daha, kendilerini özgürleştirmek için, kaçmak zorundalar: Öyküden, anlatıdan, sanat yazısından, sanat eleştirisinden, denemeden kaçmak, bunların hiçbiri olmadan tümünün içinden geçen yazılar olarak, tanımsızlıklarından beslenen özerk yazilar olmak zorundalar.” (İleri, 2007, s. 191)

Bu türsel olandan kaçış, yazara sonsuz bir yaratma özgürlüğü sunar. Bu özgürlük sayesindedir ki anlatıyı istediği gibi ters yüz edebilecektir.

Türler arasında gezinti, Karasu'nun 1985 yılında yayımlanan ilk romanı Gece'yle devam eder. Yazar, bu defa roman türüne el atmış, tek bir türe bağlı kalmaktan kaçınmayı sürdürmüştür. Gece'de yazar, iktidar tarafından bireye yönelmiş baskıyı ve bu baskının yol açtığı korku dolayısıyla firar psikolojisi içerisine girmiş bireylerin karamsar dünyasını anlatır. Gece Hareketi adındaki bir oluşum, her yere ve her şeye geceyi hâkim kılmak ister. Bu harekete bağlı olarak eylemlerini sürdüren ve kendilerine Gecenin İşçileri diyen grupsa bu baskıyı günlük hayatın olağan akışında görünür kılmaya çalışır. Karasu'nun yarattığ şeye egemen olmuştur. Bu korku, bireyleri kaçışa sürükleyen temel motivasyondur. Romanın başkarakteri N., her yere çökmüş bu korkunç atmosferin etkisiyle firar psikolojisi içerisindedir. Geceye muhalif olsa da başına bir şey gelmesinden çekinir, bu yüzden görüşlerini açıkça paylaşmaktan kaçınmaktadır. Kendisini güvende hissettiği sürece, başkalarının karşı karşıya olduğu baskı onu pek fazla ilgilendirmemektedir. Bununla birlikte romanın biçimsel yapısının çok parçalı bir görünüm göstermesi, karakterlerin birbirinin yerine geçtiği, postmodern bir anlatının inşa edilmesine olanak sağlar. Romanda anlatıcı meselesi önemli bir yapısal unsurdur. Her bölümde farklı bir anlatıcının konuştuğu romanda, hepsinin üzerinde başka bir anlatıcı vardır ki bu yolla metinde üst anlatıcı inşa edilir. Roman bittikten sonra araya girip son bir bölüm açan anlatıc1 "bunları yazmakla çıldırmaktan kurtulunur mu?" diye sorar. Bunun okura göstermiş olduğu gibi, romanda gerçek firrari kişilik N. değil, yazarın bizatihi kendisidir. Yazar, yazı aracılığıyla içinde bulunduğu baskı ortamından kaçmak istemektedir. Fakat yazarın dramı, bunun yazı yoluyla gerçekleşmeyeceğini bilmesidir. Sıkışmışlık durumu, yazarı boğar ve onu yazıya sığınmaya iter. Gece'de yazar ve kurmaca karakterler, zıt davranış kalıpları içerisinde bulunur. Metnin karakterleri, bu totaliter rejimin baskısından kaçmak istemekteyken, yazar, kendi gerçekliğinin baskısından yazının kurmacasına firar eder. "Yazmakla çıldırmaktan 
kurtulunmayacağının" en başta farkında olan kişi yazarın kendisidir, belki de bu yüzden metindeki bütün kişiler sonunda yazarın parçaları haline gelir. Okur, Gece'yi okurken bu baskıdan hiçbir zaman kurtulamayacağını hisseder. Ne kadar çabalasa da, okurun da, yazarın da, kurmaca karakterlerin de bu yerleşik hale gelmiş olan distopyadan kaçma şansı artık kalmamıştır.

Kılavuz'sa okuru firarın başka bir boyutuyla, bireyin geçmişin sorumluluğunu reddetme çabasıyla yüz yüze getirir. Üstkurmaca tekniğiyle kaleme aldığı bu romanda Karasu, gerçek ile düşün iç içe geçtiği bir ortam yaratır. Romanda iki duygu ön plandadır: Sevgi ve korku. Erkek karakterlerle dolu romanda kaçış arzusu kendisini tüm şiddetiyle hissettirir. Romanın baş karakteri Uğur, geçmişin sorumluluğundan kaçmak istediği için tatile çıkar. Bu tatilde tanışacağ Yılmaz, Mümtaz ve İhsan'la geçireceği günler onun yeniden hayata dönüşünü sağlayacaktır. Uğur'un kaçmaya çalıştığı sorumluluk, geçmişten tanıdığı Bülent'in ölümüne sebep olma ihtimalidir. Uğur, bu gerçeği yadsıyarak kendisine bir savunma mekanizması örmüştür. Heinz Hartmann, yadsımanın kökeninde kaçışın olduğunu belirtir. Gerçeklik yadsındıkça birey kaçışa sürüklenir, bu kaçışın vardığı nihai sonuçsa benin kısıtlanışıdır (Hartmann, 2016, s. 31). Uğur, uzun bir süre boyunca Bülent'in ölümündeki payını yadsıma eğiliminde olmuştur. Ancak sonunda bu ölümdeki manevi sorumluluğundan daha fazla kaçamayacağını fark eder ve bu gerçeği kabullenir. Bununla beraber bu kabullenme, beklendiği gibi bir ferahlamaya yol açmamıştır. Tam tersine, sorumluluğun bir defa kabullenilmesi, Uğur'u firar psikolojisine sürükler. Bu psikoloji, Uğur'un herkesten kaçıp Bükönü’nde tatile çıkmasına sebep olur. Burada geçireceği günleri Uğur'u İhsan'la tanıştıracak ve ikisinin ilişkisi Uğur'un kaçış fikrinden kurtulmasını sağlayacaktır. Uğur, düşlerinde sürekli ölüme dair imgeler görür. Geçmişinden bazı kişiler onun rüyalarına girip ölmesi gerektiğini söyler. Bu, Uğur'un içinde yaşadığı suçluluk duygusunun rüya anında bilinç düzeyine çıktığını gösterir.

Bükönü’nde ve ardından Turunçlu'da geçirdiği günler, Uğur'un geçmişle hesaplaşmasını sağlar. Devamlı geçmişinden kaçarak yaşamayı sürdüremeyeceğinin farkına varan Uğur, burada eski kişiliğinden sıyrılmış ve yeni bir ben olarak yeniden doğmuştur. Burada tanıştığı İhsan'la birlikte yeni bir hayata başlayabilme ihtimali onu heyecanlandırır. Uzun bir zaman sonra yeniden hayata tutunmasına sebep olacak bir şeye sahip olmanın mutluluğunu yaşar. Bu açıdan Uğur'u Karasu'nun öteki firari karakterlerinden ayıran bir şey vardır. Karasu'nun karakterleri arasında ilk defa Uğur, gerçekleştirdiği firarda başarıya ulaşır ve olumlu bir kendilik inşa etmeye başlar. Karasu, yıllar sonra metnini iyimser bir tonla bitirmeyi tercih eder. İhsan, Uğur için bir bakıma kaybettiği Bülent'in yerini dolduracak bir kişidir. Ankara’ya dönerken geçirdikleri trafik kazası, Uğur'un kendiliğini yeniden inşa etmesi için ona bir firsat sunar. Hastalığında eski sevgilisi Bülent' in yanında olamamış ve onun ölümünden kendini sorumlu tutmuş bir kişi olarak Uğur, şimdi bu hatasını telafi etme şansına sahiptir. Kazadan sonra Uğur, İhsan'ın bakımını üstlenir ve onunla yakından ilgilenmeye başlar. Bülent'in ölümüne sebep olmanın ağırlığından kurtulmanın bir yolunu sonunda bulmuştur. Uğur'un içinde bulunduğu firar psikolojisinden çıkışının yolu da buradadır. 


\section{SONUÇ}

Bilge Karasu'nun çok çeşitli şekillerde okunmaya açık olan metinlerinin merkezindeki en önemli unsurlardan biri, öykü, masal ya da romanlarındaki karakterlerin içerisinde bulunduğu kaçış arzusudur. Modern bireyin karşı karşıya kaldığ psikolojisi, kişilerin içinde bulundukları mekân, konum ya da zamandan uzaklaşarak yalnız kalma ihtiyaçlarından doğar. Bireyin psikolojisinin dış dünyaya karşı oluşturduğu savunma mekanizmalarının etkisiyle toplumla sağlıklı ilişkiler kurmayı başaramamasının sonucunda birey, kendisini her şeyden ve herkesten uzaklaştırır. Kaçış, bireyin psikolojik dünyasındaki kırılganlıklarının doğrudan sonucu olabileceği gibi toplum tarafından kendisine yönelmiş baskı sebebiyle de açığa çıkabilir. Sebep her ne olursa olsun, çağdaş yaşantıda firari bireylerin toplumsal yaşantının her noktasında mevcut olduğu bir gerçektir.

Modern Türk edebiyatı, başlangıcından günümüze yenilikçi yazarlar tarafından kaleme alınmış, firar psikolojisi içerisinde olan bireylerin merkeze alındığg ya da bir konu olarak doğrudan kaçış fikrinin incelendiği metinlerle doludur. Modern Türk edebiyatında başlı başına bir edebi eğilim oluşturan firar anlatısının en yetkin örneklerinden bazıları Bilge Karasu'nun metinleridir. Şahsi yaşantısıyla da firari bir kişilik ortaya koyan Karasu, edebi metinlerinde bu kaçış anlatısını sürdürür ve öykülerinin merkezine kaçış arzusu içerisinde olan karakterler yerleştirir. Karasu'da kaçış, yalnızca içerik olarak kendisini göstermekle kalmaz, verili dilden bilinçli şekilde yapılan sapmalar ve hiçbir edebi türe bağlı kalmama isteği olarak da açığa çıkar. Kapalı bir anlatımla kaleme aldığı metinlerinde sabit bir türe sadık kalmaktan uzaktır. Öykülerin yanında masal, roman, metin, günlük, şiir gibi farklı türlerde eser meydana getiren Karasu'nun metinlerinde konular değişse de firar anlatısı ve bireyin kaçış arzusu kendisini her defasında göstermeyi sürdürür. Bu sebeple, Karasu'nun metinlerinde yer alan bireyin ana meselesinin içinde bulunduğu kaçış arzusu olduğunu söylemek mümkündür.

\footnotetext{
Hakem Değerlendirmesi: Dış bağımsız.

Çıkar Çatışması: Yazar çıkar çatışması bildirmemiştir.

Finansal Destek: Yazar bu çalışma için finansal destek almadığını beyan etmiştir.
}

Peer-review: Externally peer-reviewed.

Conflict of Interest: The author has no conflict of interest to declare.

Grant Support: The author declared that this study has received no financial support.

\section{KAYNAKÇA/REFERENCES}

Adler, A. (2018). Bireysel psikoloji (Ali Kılıçlığlu, Çev.). İstanbul: Say Yayınları.

Akatlı, F. ve Sökmen, M. G. (Haz.). (2019). Bilge Karasu aramızda. İstanbul: Metis Yayınları.

Armağan, Y. (2017). Imkânsız Özerklik: Türk şiirinde modernizm. İstanbul: İletişim Yayınları.

Bachelard, G. (2018). Mekânın poetikası (Alp Tümertekin, Çev.). İstanbul: İthaki Yayınları. 
Badiou, A. (2019). Etik: Kötülük kavrayışı üzerine bir deneme (Tuncay Birkan, Çev.). İstanbul: Metis Yayınlar1.

Canetti, E. (2019). Kitle ve iktidar (Gülşat Aygen, Çev.). İstanbul: Ayrıntı Yayınları.

Dirlikyapan, J. Ö. (2017). Kabuğunu kıran hikâye: Türk öykücülüğünde 1950 kuşă̆ı. İstanbul: Metis Yayınlar1.

Ecevit, Y. (2017). Ben buradayım: Ŏguz Atay’ın biyografik ve kurmaca dünyası. İstanbul: Metis Yayınları.

Foucault, M. (2019). Hapishanenin doğuşu: Gözetim altında tutmak ve cezalandırmak (Mehmet Ali Kılıçbay, Çev.). Ankara: İmge Kitabevi Yayınları.

Freud, A. (2017). Ben ve savunma mekanizmaları (Yeşim Erim, Çev.). İstanbul: Metis Yayınları Hartmann, H. (2016). Ben psikolojisi ve uyum sorunu (Banu Büyükkal, Çev.) İstanbul: Metis Yayınları İleri, C. (2007). Yazının da yırtılıverdiği Yer: Bir Bilge Karasu okuması. İstanbul: Metis Yayınları.

Karasu, B. (2017). Göçmüş Kediler Bahçesi. İstanbul: Metis Yayınları.

Karasu, B. (2019). Gece. İstanbul: Metis Yayınları.

Karasu, B. (2013). Halûk'a Mektuplar. İstanbul: Metis Yayınları.

Karasu, B. (2011). Imbilim Ders Notları. Ankara: BilgeSu Yayıncılık.

Karasu, B. (2013). Jean ve Gino'ya Mektuplar. İstanbul: Yap1 Kredi Yayınları.

Karasu, B. (2016). Kllavuz. İstanbul: Metis Yayınları.

Karasu, B. (2016). Klsmet Büfesi. İstanbul: Metis Yayınları.

Karasu, B. (2017). Nasıl Yazıyorsam Öyleyimdir. İstanbul: Kırmızı Kedi Yayınevi.

Karasu, B. (2015). Ne Kitapsız Ne Kedisiz. İstanbul: Metis Yayınlar1.

Karasu, B. (2016). Öteki Metinler. İstanbul: Metis Yayınları.

Karasu, B. (2017). Susanlar. İstanbul: Metis Yayınları.

Karasu, B. (2019). Troya'da Ölüm Vardl. İstanbul: Metis Yayınları.

Karasu, B. (2017). Uzun Sürmüş Bir Günün Akşamı. İstanbul: Metis Yayınları.

Klein, M. (2020). Haset ve Şükran (Orhan Koçak, Yavuz Erten, Çev.). İstanbul: Metis Yayınları. Masterson, J. F. (2016). Gerçek kendilik (Pınar Üzeltüzenci, Çev.). İstanbul: Litera Yayıncılık Parla, J. (2018). Türk romanında yazar ve başkalaşım. İstanbul: İletişim Yayınları. Yaşat, D. (Haz.). (2017). Bilge Karasu'yu okumak. İstanbul: Metis Yayınları. 